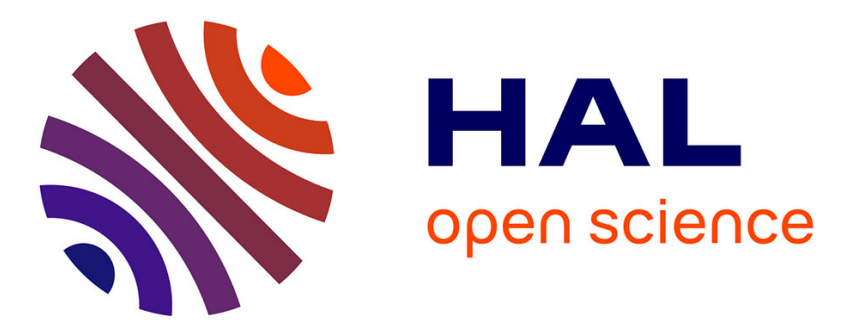

\title{
Coupling biophysical and micro-economic models to assess the effect of mitigation measures on greenhouse gas emissions from agriculture
}

Sophie Durandeau, Benoit Gabrielle, Caroline Godard, Pierre-Alain Jayet, Christine Le Bas

\section{To cite this version:}

Sophie Durandeau, Benoit Gabrielle, Caroline Godard, Pierre-Alain Jayet, Christine Le Bas. Coupling biophysical and micro-economic models to assess the effect of mitigation measures on greenhouse gas emissions from agriculture. Climatic Change, 2010, 98 (1-2), pp.51-73. 10.1007/s10584-009-9653-8 . hal-00410001

\section{HAL Id: hal-00410001 https://hal.science/hal-00410001}

Submitted on 14 Aug 2009

HAL is a multi-disciplinary open access archive for the deposit and dissemination of scientific research documents, whether they are published or not. The documents may come from teaching and research institutions in France or abroad, or from public or private research centers.
L'archive ouverte pluridisciplinaire HAL, est destinée au dépôt et à la diffusion de documents scientifiques de niveau recherche, publiés ou non, émanant des établissements d'enseignement et de recherche français ou étrangers, des laboratoires publics ou privés. 
1. Coupling biophysical and micro-economic models to 2 assess the effect of mitigation measures on greenhouse gas emissions from agriculture

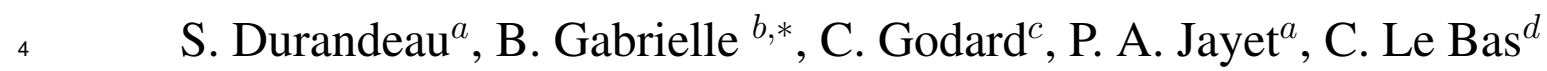

5 a: INRA, AgroParisTech, UMR 210 Économie Publique, F-78850 Thiverval-Grignon, France.

6 b: INRA, AgroParisTech, UMR 1091 Environnement et Grandes Cultures, F-78850 Thiverval-

7 Grignon, France.

s c: Agro-Transfert Ressources et Territoires, 2 chaussée Brunehaut - F-80200 Estrées-Mons,

9 France.

d: INRA, US 1106 INFOSOL, F-45166 Olivet, France.

$11 \quad *$ : Corresponding author:

Institut National de la Recherche Agronomique, AgroParisTech

Fax: (+33) 130815551 


\section{Abstract}

Agricultural soils are a major source of atmospheric nitrous oxide $\left(\mathrm{N}_{2} \mathrm{O}\right)$, a potent greenhouse gas (GHG). Because $\mathrm{N}_{2} \mathrm{O}$ emissions strongly depend on soil type, climate, and crop management, their inventory requires the combination of biophysical and economic modeling, to simulate farmers' behavior. Here, we coupled a biophysical soil-crop model, CERES-EGC, with an economic farm type supply model, AROPAj, at the regional scale in northern France. Response curves of $\mathrm{N}_{2} \mathrm{O}$ emissions to fertilizer nitrogen (Nf) inputs were generated with CERES-EGC, and linearized to obtain emission factors. The latter ranged from 0.001 to $0.0225 \mathrm{~kg} \mathrm{~N}_{2} \mathrm{O}-\mathrm{N} \mathrm{kg}^{-1} \mathrm{Nf}$, depending on soil and crop type, compared to the fixed 0.0125 value of the IPCC guidelines.

The modeled emission factors were fed into the economic model AROPAj which relates farmlevel GHG emissions to production factors. This resulted in a $\mathrm{N}_{2} \mathrm{O}$ efflux $20 \%$ lower than with the default IPCC method. The costs of abating GHG emissions from agriculture were calculated using a first-best tax on GHG emissions, and a second-best tax on their presumed factors (livestock size and fertilizer inputs). The first-best taxation was relatively efficient, achieving an $8 \%$ reduction with a tax of $11 € / \mathrm{t}-\mathrm{CO}_{2}$-equivalent, compared to $68 € / \mathrm{t}-\mathrm{CO}_{2}$ eq for the same target with the second-best scheme.

Keywords: nitrous oxide, agro-ecosystem model, economic modeling, greenhouse gas, mitigation measures

Abbreviations: GHG - Greenhouse Gas ; Nf - Fertilizer nitrogen ; IPCC - Intergovernmental Panel on Climate Change ; CAP - Common Agricultural Policy ; FADN - Farm Accountancy Data Network ; t- $\mathrm{CO}_{2}$-eq - t DM-CO ${ }_{2}$-equivalent ; LU - Livestock Unit; CERES-EGC: agroecosystem model simulating $\mathrm{N}_{2} \mathrm{O}$ emissions; STICS: agro-ecosystem model simulating crop yields; AROPAj: economic farm model including GHG emissions; NOE: algorithm predicting $\mathrm{N}_{2} \mathrm{O}$ emissions from soil drivers. 


\section{Introduction}

\section{1 $\quad \mathrm{N}_{2} \mathrm{O}$ emissions in agriculture}

The global abundance of nitrous oxide $\left(\mathrm{N}_{2} \mathrm{O}\right)$ in the atmosphere was $319.2 \mathrm{ppb}$ in 2004 , and had been increasing at a rate of $0.74 \mathrm{ppb}$ per year over the past decade WMO and WDCGG (2006). Nitrous oxide is a potent greenhouse gas, with a global warming potential about 300 times higer than the carbon dioxide $\left(\mathrm{CO}_{2}\right)$. It is the third contributor to anthropogenic global warming, after $\mathrm{CO}_{2}$ and methane $\left(\mathrm{CH}_{4}\right)$. Nitrous oxide is naturally emitted from soils and oceans, but human activities also contribute a third of its overall release (WMO and WDCGG, 2006). Policy measures aiming at abating anthropogenic emissions of $\mathrm{N}_{2} \mathrm{O}$ are thus being actively sought. At the country level, the agricultural sector is generally the first anthropogenic source of $\mathrm{N}_{2} \mathrm{O}$. In France, its share was estimated at 76\% in 2004 (CITEPA, 2008), when summing the emissions related to land-use and to the use of synthetic fertilizer nitrogen (Nf).

Agricultural $\mathrm{N}_{2} \mathrm{O}$ emissions are known to depend on $\mathrm{Nf}$ inputs of to a large extent (Houghton et al., 1996). Besides, excessive use of fertilizer $\mathrm{N}$ is also responsible for the increase of nitrate leaching (Beaudoin et al., 2005; Schnebelen et al., 2004) and ammonia $\left(\mathrm{NH}_{3}\right)$ emissions (Herrmann et al., 2001). Nitrate pollution of groundwater is a well-known environmental problem, particularly harmful for aquatic ecosystems, while $\mathrm{NH}_{3}$ is a major atmospheric pollutant with impacts on atmospheric chemistry and on the stability and the biodiversity of terrestrial and aquatic ecosystems (Asman et al., 1998). However, the emission of these reactive $\mathrm{N}$ compounds are not solely related to fertilizer inputs, inasmuch as they occur throughout the $\mathrm{N}$ cycle in the soil. Complex processes involving soil microbiology affect the dynamics of inorganic and organic forms of nitrogen in the soil, with the result that $\mathrm{N}$ losses by arable systems are tightly related to environmental conditions, and chiefly climatic sequence and soil type. 


\subsection{Coupling economic and biophysical models to assess $\mathrm{N}_{2} \mathrm{O}$ emissions}

The Kyoto protocol (1997) is an agreement made under the United Nations Framework Convention on Climate Change. It requires signatory countries to inventory and report emissions for a set of greenhouse gases (GHG), including $\mathrm{N}_{2} \mathrm{O}$ on an annual basis to monitor their time course. Guidelines were set up by the Intergovernmental Panel on Climate Change (IPCC) to help these countries in their national inventories (Houghton et al., 1996), with a tiered approach. The simplest and most used methodology provided by the IPCC (Tier 1) relies on generic, fixed factors to convert national statistics on economic activities into GHG emissions. Because these factors are default ones, they should not be considered as an exclusive standard. Caution is expressed in the guidelines regarding "the default assumptions and data which are not always appropriate for specific national contexts". The development of alternative methodologies, as permitted under the Tiers $2 \& 3$ ot the latest IPCC guidelines (IPCC, 2006), thus appears as a promising way to assess GHG emissions more accurately.

The major shortcoming of the IPCC default method lies in its ignoring the complexity of the microbiological processes responsible for $\mathrm{N}_{2} \mathrm{O}$ emissions (nitrification and denitrification; Firestone and Davidson 1989). Also, it is necessary to take into account the effects of soil characteristics, climate, crop management and land use in the assessment of the $\mathrm{N}_{2} \mathrm{O}$ emissions (Granli and Bockman, 1995; Smith et al., 1998; Ruser et al., 2001), and their variability in both space and time (Kaiser et al., 1998; Dobbie et al., 1999; Smith et al., 2004).

Contrary to the IPCC Tier 1 method, biophysical soil-crop models have the potential to deal with these drivers, and may be used to assess more accurately the amounts of $\mathrm{N}_{2} \mathrm{O}$ emitted from agricultural soils, in relation to crop management (Neufeldt et al., 2006). As those models integrate the complexity of nitrogen cycles pathways in the soil-crop-atmosphere system, they are also expected to provide a rather fine assessment of other forms of $\mathrm{N}$ losses as well (among which 
$\mathrm{NO}_{3}^{-}, \mathrm{NH}_{3}$ and $\mathrm{NO}$ ). However, while there exist spatially-explicit maps for the biophysical input parameters of these models (including soil properties and climatic data), information on crop management on the same mapping units proves much more challenging to infer because of the variety of agricultural production systems present within a given geographical zone. Such data are usually obtained through field surveys, regional statistics or farm accountancy data, but their scales do not match that of the spatial units relevant to the biophysical processes at stake (Leip et al., 2008). Intersecting the two levels practically implies the use of agricultural fields as elementary objects. Economic models at the farm level provide a unique means of predicting and scaling down management data from aggregated statistics. Coupling economic and biophysical models has therefore emerged as a promising route to address the environmental impacts of agriculture and their regulation (Vatn et al., 1999; Godard et al., 2008), tackling the issue of spatial and temporal variability in environmental losses. However, because economic and biophysical models do not operate at the same level, disaggregation techniques are required to generate management information at the scale relevant to biophysical processes. These include econometrics, Bayesian inference of spatial distribution parameters based on physical co-variables (Leip et al., 2008), and expert knowledge (Godard et al., 2008; Godard, 2005).

Recent work has underlined the usefulness of such coupling in the estimation of GHG emissions from agriculture at regional (Neufeldt et al., 2006) to continental (Leip et al., 2008) level. The latter authors fed outputs from economic modeling of agricultural activities at farm or regional level to a biophysical model, DNDC (Li et al., 1992), to predict the GHG balances of statistically representative farms or homogeneous simulation units. They highlighted the large variability of $\mathrm{N}_{2} \mathrm{O}$ emissions across landscape, soil, climate characteristics and farming systems. However, they did not address the effects of taking this variability into account when designing policies to regulate GHG emissions from agriculture, which is the focus of this paper. In principle, it should 
allow more accurate studies on the effects of public policies, because agro-ecosystem models can deal with heterogeneities occuring at finer scales.

\subsection{Modeling the efficiency of mitigation measures for greenhouse gas emis- sions from agriculture}

For countries having ratified the Kyoto Protocol, there is a need to investigate the efficiency of GHG mitigation measures, including their economic costs. Economic models have a capacity to simulate the impact of various policy scenarios of the agricultural sector, in our case. Coupling them with biophysical agro-ecosystem models is thus a promising way to appraise the efficiency of pollution mitigation policies, and of GHG emissions in particular. Economic regulation aiming at mitigating environmental damage leads to consider two standardized taxing schemes: a first-best scheme levying a tax on the direct damage, such as the quantity of pollutants dumped into the environment; and a second-best scheme taxing the presumed factors of the damages incurred (Henry, 1989; De Cara and Jayet, 2000b). First-best taxing allows a very tight linkage with damages, and thereby theoretically the best economic efficiency in its abatement. It usually refers to an ideal world where information is fully accessible and transaction costs are as small as possible. Although the underlying assumptions are never satisfied in the real world, the first-best option provides the 'best possible world' reference. Namely, in our case, this situation refers to a world where farmers do actually optimize their $\mathrm{N}$ fertilizing level to maximize their profit, based on their knowledge of the relationships between yield and GHG emissions and Nf rates. It implies they would make the most of the information currently provided to AROPAj by the biophysical models. This reference corresponds to what could be expected in terms of welfare, including environmental economics, when the best options are implemented into the system. However, it requires a detailed knowledge of the actual damage, an information which is very costly if not impossible to obtain. In practice, it is thus more convenient to consider the 
production factors presumed to be responsible for the damage, which may be better-known and measurable. This leads to the implementation of a second-best taxation, which usually results in a loss in the efficiency of the mitigation measure ${ }^{1}$. Second best options are obviously more relevant for policy makers, and incur a loss of welfare which is interesting to assess. Here, we investigated two possible measures for the reduction of GHG emissions from agriculture, using either a first-best tax on the GHG emissions or a second-best tax on their presumed management factors

Godard et al. (Godard et al., 2008; Godard, 2005) coupled the biophysical crop-model STICS (Brisson et al., 1998) and the economic farm type model AROPAj (De Cara and Jayet, 2000a), which is based on the European data of the Farm Accountancy Data Network (FADN; see section 2.2 for a detailed presentation). This linkage made it possible to simulate the response of crop yields to fertilizer nitrogen (Nf), in various regions of the European Union (EU), and thereby predict the effect of various GHG emissions taxation scenarios on farmers' crop management practices. Currently, with the AROPAj model, the consequences in terms of GHG emissions at the farm type level were estimated using the optimized Nf doses and the IPCC default emission factor of $1.25 \%$ for $\mathrm{N}_{2} \mathrm{O}$ (whereby $1.25 \%$ of applied $\mathrm{Nf}$ is evolved as $\mathrm{N}_{2} \mathrm{O}$ ).

Here, we set out to further the analysis by using a biophysical crop model to predict the $\mathrm{N}_{2} \mathrm{O}$ emissions, instead of the fixed emission factor of the IPCC Tier 1 methodology. Such an approach allows for improved relationships between farming activities and $\mathrm{N}$ pollution, and should benefit the economic analysis of GHG emissions and mitigation. This is especially relevant since agriculture is a major contributor to $\mathrm{N}_{2} \mathrm{O}$ emissions. This paper thus focuses on the derivation of $\mathrm{N}_{2} \mathrm{O}$ emission functions and on the impact of their implementation in an agricultural economic model, regarding GHG emissions and the efficiency of two GHG taxation schemes. Ideally, the 
same biophysical model could have have been used to simulate both the response of crop yields to $\mathrm{Nf}$ and the emissions of $\mathrm{N}_{2} \mathrm{O}$. However, because the STICS model does not simulate $\mathrm{N}_{2} \mathrm{O}$ emissions as yet, we had to use another one for $\mathrm{N}_{2} \mathrm{O}$. We selected the CERES-EGC crop model (Gabrielle et al., 2006a) for the coupling, as it struck a good balance between process description level and ease of use.

The objectives of this work were thus three-fold: i/ to build response curves relating $\mathrm{N}_{2} \mathrm{O}$ emissions from cropland to fertilizer $\mathrm{N}$ application rates using the CERES-EGC model, ii/ to input these results to the economic model AROPAj to assess the regional $\mathrm{N}_{2} \mathrm{O}$ emissions from agriculture, and iii/ to investigate the effects of various mitigation measures. We focused on the Picardie region in Northern France, but the following methodology could easily be extrapolated to any FADN region within the EU.

\section{Materials and Methods}

\subsection{The biophysical model CERES-EGC}

CERES-EGC was adapted from the CERES family of soil-crop models, which have been extensively tested worldwide for more than 20 years (see Jones et al. (2005) for a review). This particular version focuses on environmental outputs (nitrate leaching, gaseous emissions of $\mathrm{N}_{2} \mathrm{O}$, ammonia and nitrogen oxides). It comprises sub-models that simulate the major processes governing the cycles of water, carbon and nitrogen in soil-crop systems, on a daily time step. A physical module simulates the transfer of heat, water and nitrate down the soil profile, as well as soil evaporation, plant water uptake and transpiration in relation to climatic demand. Water infiltrates down the soil profile following a tipping-bucket approach, and may be redistributed upwards after evapo-transpiration has dried some soil layers. In both of these equations, the generalized Darcy's law has subsequently been introduced in order to better simulate water dynamics in fine-textured soils. A microbiological module simulates the turnover of organic matter 
in the plough layer, involving both mineralization and immobilization of inorganic $\mathrm{N}$ (Gabrielle and Kengni, 1996). Ammonia volatilization is calculated using a classical resistance model for turbulent transport between the soil surface and the atmosphere, and physico-chemical equilibriums in the liquid and gaseous phases of the topsoil, as a function of soil $\mathrm{pH}$ and ammonium concentration. The model is available for a wide range of crops, and was tested against experimental data for a broad range of agronomic and pedoclimatic situations, mostly in France and in Europe, for the simulation of crop yields, soil water and $\mathrm{N}$ dynamics, nitrate leaching, or gaseous losses (Gabrielle and Kengni, 1996; Gabrielle et al., 2002; Rolland et al., 2008). In particular, it was used to simulate $\mathrm{N}_{2} \mathrm{O}$ emissions from wheat crops at the field and regional scales (Gabrielle et al., 2006a,b; Gabrielle and Gagnaire, 2007), using a large database of field-scale observations over Northern France (Lehuger et al., 2008). Figure 1 presents a general schematic of the model, with the various modules involved.

NOE is the semi-empirical sub-model used in CERES-EGC to simulate the production and reduction of $\mathrm{N}_{2} \mathrm{O}$ in agricultural soils (Hénault et al., 2005). NOE simulates $\mathrm{N}_{2} \mathrm{O}$ release through the denitrification and nitrification pathways. The total denitrification of soil $\mathrm{NO}_{3}^{-}$is calculated as the product of a soil-specific potential rate with three unit-less factors related to soil water content, nitrate content and temperature. The fraction of denitrified nitrate that evolves as $\mathrm{N}_{2} \mathrm{O}$ is then considered as constant for a given soil type. Nitrification is modeled as a Michaëlis-Menten reaction, with $\mathrm{NH}_{4}^{+}$as substrate. The corresponding rate is multiplied by unit-less modifiers related to soil water content and temperature. A soil-specific proportion of total nitrification evolves as $\mathrm{N}_{2} \mathrm{O}$. 


\subsection{The AROPAj economic farm-type model}

AROPAj is a linear programming model which simulates the agricultural supply of the European Union regions (De Cara and Jayet, 2000a; Godard et al., 2008). For a given economic situation (i.e. a set of prices, taxes and policy measures), it provides an assessment of the type and amount of the agricultural products delivered on the markets. This model is mostly used to study the successive reforms of the Common Agricultural Policy (CAP) of the European Union (Jayet and Labonne, 2005), but it has been used also to address global agro-environmental problems such as agricultural GHG emissions (De Cara et al., 2005).

AROPAj is built as a set of independent sub-models, each of them simulating the behavior of a category of producers as related to a 'farm-type' (Chakir et al., 2005). The farm types result from the clustering of individual farms described in the Farm Accounting Data Network (FADN), using (i) FADN normalized farm types, (ii) elevation class, and (iii) normalized economic size. Clustering is done at the FADN-Region level. Farm types are weighted by a parameter estimated through the individual weights provided by the FADN. These farm types are statistically representative of actual production systems at the regional level, and reflect the behavior of the farmers assuming that they optimize their gross margin. A detailed presentation of the AROPAj model is available in (Chakir et al., 2005; De Cara and Jayet, 2000a), while additional information is also provided by deliverables from the GENEDEC project $^{1}$. In the version of the AROPAj model used in this study, French agriculture is divided into 131 farm types, among which 4 are located in the Picardie Region.

Figure 2 presents a schematic of the AROPAj model, deatailing its input parameters, constraints, and outputs. The variables taken into account in AROPAj include the area of each crop (among a total of 32 crop activities), the livestock size per animal type (with 31 pre-defined classes),

\footnotetext{
${ }^{1}$ http://www.grignon.inra.fr/economie-publique/genedec/eng/enpub.htm
} 
the quantity of meat, milk, grains or other crop types produced, the quantity of animal feed purchased, and the opportunity cost of land.

[Figure 2 about here.]

AROPAj includes a GHG calculation module inventorying around 20 sources of $\mathrm{CH}_{4}$ and $\mathrm{N}_{2} \mathrm{O}$ from livestock and arable farming, based on the IPCC Tier 1 guidelines. Methane is produced by enteric fermentation of mono-gastric livestock, manure management, and rice cultivation. Nitrous oxide is mostly produced by agricultural soils as a result of mineral $\mathrm{Nf}$ application, manure application as well as soil incorporation of crop residues. The model assumes that the most important factors behind GHG emissions may be assumed to be livestock size (for $\mathrm{CH}_{4}$ and $\mathrm{N}_{2} \mathrm{O}$ ), and nitrogen fertilizer use (for $\mathrm{N}_{2} \mathrm{O}$ ) (De Cara et al., 2005). By default, $\mathrm{N}_{2} \mathrm{O}$ emissions from soils are assumed proportional to Nf inputs (Bouwman, 1996), ignoring the background emissions (considered non-anthropogenic). Thus, $\mathrm{N}_{2} \mathrm{O}$ emissions represent a fixed fraction of the inputs. This fraction, referred to as the emission factor, is set to $1.25 \%$ by default in the Tier 1 methodology (Houghton et al., 1996). However, the emission factor may be varied in AROPAj, in order to explore alternative estimation methods.

In the implementation of AROPAj we used, it is important to note that the utilized arable area for each farm-type is constant. Also, cattle farmers have the possibility to adjust their livestock within a range from $85 \%$ up to $115 \%$ of their initial size. Within AROPAj it is possible to introduce various mitigation measures, such as taxes on GHG emissions, on animals or on the fertilizer $\mathrm{N}$ use, and to examine their effects on the model outputs. 
The coupling is based on the introduction in AROPAj of two mathematical relationships, relating $\mathrm{Nf}$ rates to crop yields and $\mathrm{N}_{2} \mathrm{O}$ emissions, respectively. The former were generated with the methodology developed by Godard et al. (2008), by running the STICS model over a range of $\mathrm{Nf}$ rates for various possible combinations of other crop production factors (soil type, crop management practices, climate) specific to each farm type. The methodology to determine those factors and the input data is detailed in Godard et al. (2008). Thus, a series of points (Nf rate and crop yield) were obtained for each crop in all farm types, and an exponential function was fitted to these series. Such a form of function met economic requirements for the estimation of a mathematical optimum (ie, a concave shape with 1st derivative greater than 0 ), being altogether consistent with the expected agronomic response (Godard et al., 2008). Hence, the following function was selected :

$$
Y(N f)=Y \max -(Y \max -Y \min ) \times e^{-\tau N f}
$$

where $\mathrm{Y}(\mathrm{Nf})$ is the crop yield (in $\left.\mathrm{t} \mathrm{ha}^{-1}\right), \mathrm{Nf}$ is the fertilizer $\mathrm{N}$ rate $\left(\mathrm{kg} \mathrm{N} \mathrm{ha}^{-1}\right), \tau$ the rate of increase (curvature) of the yield function, and Ymin and Ymax are the minimum and maximum (asymptotic) yields, respectively. This relationship was derived by running the STICS model with the same input data and adjustment procedure as Godard et al. (2008).

The relationship between $\mathrm{N}_{2} \mathrm{O}$ emissions and $\mathrm{Nf}$ was generated by running the CERES-EGC models in the same conditions as with the yield response curve, namely the same biophysical inputs and $\mathrm{Nf}$ range for each crop in all farm types. The resulting yearly $\mathrm{N}_{2} \mathrm{O}$ emissions curves were regressed against $\mathrm{Nf}$ assuming a straight-line, following the 'emission factor' approach of the IPCC Tier 1 methodology. 


\subsubsection{Simulation scenarios with the coupled models AROPAj and CERES-EGC}

The two relationships Nf-yield response curve and $\mathrm{N}_{2} \mathrm{O}$ emission factor were fed into the AROPAj model. The yield response curves were input in the form of the exponential function given in eq. 1, specific for each crop of each farm type, as were with the $\mathrm{N}_{2} \mathrm{O}$ emission factors generated with the CERES-EGC simulations. An exception was made for the crops not simulated with CERES-EGC, in which case the IPCC default value of $1.25 \%$ was used. The CAP agenda 2000 scenario (De Cara et al., 2005) was implemented in the economic model that was also run under a set of taxation rules, in which case the farmers could be expected to adjust their fertilizer doses taking into account these new economic environment. The objective of this paper was to study the variation of $\mathrm{N}_{2} \mathrm{O}$ emissions and the effect on them of various taxation scenarios, under various modeling assumptions relating the biophysical model CERES-EGC and the economic model AROPAj . After having checked the consistency of the yield-Nf response curves obtained with the CERES-EGC and the STICS models, the $\mathrm{N}_{2} \mathrm{O}$ emissions factors were computed from the CERES-EGC simulations. Two simulation scenarios for crop yields and two simulation scenarios for $\mathrm{N}_{2} \mathrm{O}$ emission factors were tested. In the first variant for yields (referred to as EXOG in the following), the yields were considered constant and fixed at the values given in the FADN for each crop and farm type. The total nitrogen fertilizer inputs were estimated based on the costs of each crop and farm type, as extracted from the FADN data. In the second variant for crop yields (noted ENDOG), the yields and the fertilizers rates were calculated by optimizing the field's gross margins based on the response curves. This led to solve simple mathematical programs of the type ' $\max _{N} f[p Y(N f)-w N f]$ subject to $N f \geq 0$ ', where $\mathrm{Nf}$ is fertilizer $\mathrm{N}$ input rate, $\mathrm{p}$ is the crop selling price, $\mathrm{Y}(\mathrm{Nf})$ is the crop yield, and $\mathrm{w}$ is the market price of fertilizer N. Within this "ENDOG" scenario, changes in fertilizer costs due to taxes on this commodity are expected to alter the optimum $\mathrm{Nf}$ rate. For comparison with the IPCC method, the $\mathrm{N}_{2} \mathrm{O}$ emissions of the farm types were assessed with AROPAj either with the default emission factor (noted IPCC) or 
with the CERES-EGC derived emission factors (noted CERES). Table 1 summarizes the four simulation scenarios tested with the AROPAj micro-economic model.

[Table 1 about here.]

\subsection{Crop simulations at the regional level}

Since this work directly follows that of Godard et al., and involves comparison with her results, we chose the same simulation conditions. We focused on the Picardie region (northern France), which is characterized by an important agricultural activity based on intensive cereal, sugar beet, potato, oil and protein-producing crops. Its climate is temperate and mild, with marine influence. The annual rainfall is $630 \mathrm{~mm}$, and the mean annual air temperature is $10.6{ }^{\circ} \mathrm{C}$. In the AROPAj model, the Picardie region is represented by four farm types $(\mathrm{CrPi} 1, \mathrm{CrPi} 2, \mathrm{CaPi} 1$, and $\mathrm{CaPi} 2)$ representing, respectively, 2819, 4786, 2116, and 1002 real farms. They involve both arable and arable-livestock farming. The harvest year of the simulations is 1997 because the economic data used by AROPAj are derived from the FADN data for this particular year. Since all farm types belong to the same AROPAj altitude class (namely, less than 300 meters above sea level), we considered only one set of daily weather data for the whole Picardie region (Godard et al., 2008). We used weather data for the years 1995 through 1997, to take into account the preceding crop. The main data sources and methods to estimate inputs for the biophysical models are listed in Table 2. Readers are referred to Godard et al. (2008) for a full description of these databases. The characteristics of the cases studied in Picardie are presented in Tables 3 (for the farm types and crops) and 4 for soils' properties. CERES-EGC uses the same soil parameters as STICS with the exception of specific additional parameters needed by the nitrification and denitrification routines. Those were obtained from references involving similar soil types, as listed in Table 4.

[Table 2 about here.] 
Simulations with the CERES-EGC model for the studied cases for yield and $\mathrm{N}_{2} \mathrm{O}$ Nf-response curves were carried out with yearly $\mathrm{Nf}$ rates varying from 0 to $400 \mathrm{~kg} \mathrm{~N} \mathrm{ha}^{-1}$, in $20 \mathrm{~kg} \mathrm{~N} \mathrm{ha}^{-1}$ increments.

[Table 3 about here.]

[Table 4 about here.]

The variation in the earliness implies a variation in the dates of the phenological stages of the crops, and thus in the fertilizers application dates (Godard, 2005). We started the simulations upon sowing of the preceding crop in order to smooth out the effects of initial soil conditions setting. The preceding crop was either a non-fertilized pea or a fertilized soft wheat. Since we focused on $\mathrm{N}$-losses in relation to $\mathrm{Nf}$ application, and because the processes in the nitrogen cycle responsible for the various $\mathrm{N}$-losses do not instantly respond to $\mathrm{Nf}$ inputs, it may be relevant to include the $\mathrm{N}$ losses occurring over the next few years of the crop rotation. However, as the economic model only takes into account the year of the FADN data (1997, in this case), we only used the $\mathrm{N}$-loss estimates for this year.

Not all crops grown in Picardie could be simulated by the CERES-EGC model: such was the case for potato and sunflower, which have not yet been implemented in the model. However, as shown in Table 5, we worked with the major crops present in Picardie: wheat, barley, maize, rapeseed and sugar beet cultivation made up 74\% of the total arable area of the region in 1997 (AGRESTE, 1997). For the crops that were not simulated with CERES-EGC, we kept the default yield and Nf values, i.e. the ones from the FADN of the year 1997. Since there was some livestock farming in the region, manure $\mathrm{N}$ was taken into account in the yield response curves simulated by STICS (Godard et al., 2008). Emissions of GHG from manure handling and spreading are included in AROPAj, based on IPCC guidelines and regional coefficients. Since CERES-EGC was not used to simulate the direct emissions of $\mathrm{N}_{2} \mathrm{O}$ resulting from manure application, there were no 
modeled emission factors for manure $\mathrm{N}$ input and we used the IPCC Tier 1 emission factor of $0.0125{\mathrm{~kg} \mathrm{~N}-\mathrm{N}_{2}}_{2} \mathrm{O} \mathrm{kg}^{-1} \mathrm{Nf}$.

[Table 5 about here.]

\section{Results and discussion}

\subsection{Response of $\mathrm{N}_{2} \mathrm{O}$ emissions to nitrogen fertilizer inputs}

\subsubsection{Simulation of $\mathrm{N}_{2} \mathrm{O}$ emissions across crops and farm types}

[Figure 3 about here.]

Figure 3 presents the $\mathrm{N}_{2} \mathrm{O}$ emissions simulated with the CERES-EGC crop-model, for $\mathrm{Nf}$ rates varying from 0 to $400 \mathrm{~kg} \mathrm{~N} \mathrm{ha}^{-1}$, in the various regional cases. Generally, $\mathrm{N}_{2} \mathrm{O}$ emissions increased as Nf increased. Strong differences occurred between the cases in the magnitude of the $\mathrm{N}_{2} \mathrm{O}$ emissions. For a $400 \mathrm{~kg} \mathrm{~N}$ ha $^{-1}$ fertilizer input, $\mathrm{N}_{2} \mathrm{O}$ emissions reached as much as $3.5 \mathrm{~kg} \mathrm{~N}_{2} \mathrm{O}-\mathrm{N} \mathrm{ha}{ }^{-1}$ for soft wheat, and nearly $11 \mathrm{~kg} \mathrm{~N}_{2} \mathrm{O}-\mathrm{N} \mathrm{ha}^{-1}$ for sugar beet. In the medium range of $\mathrm{Nf}$ (around $200 \mathrm{~kg} \mathrm{~N} \mathrm{ha}^{-1}$ ) corresponding to the actual application rates determined with the Nf yield response curves (Godard et al., 2008), the emissions rates ranged from 0.60 for winter barley to $7.61 \mathrm{~kg} \mathrm{~N}_{2} \mathrm{O}-\mathrm{N}$ ha ${ }^{-1}$, and averaged about $2.94 \mathrm{~kg} \mathrm{~N}_{2} \mathrm{O}-\mathrm{N}$ ha ${ }^{-1}$ across the various cases. This value is very close to the average flux of $2.7 \mathrm{~kg} \mathrm{~N}_{2} \mathrm{O}-\mathrm{N} \mathrm{ha}{ }^{-1}$ reported by (Leip et al., 2008) for the whole of France with a similar mean application rate $\left(201 \mathrm{~kg} \mathrm{~N} \mathrm{ha}^{-1}\right)$, and to the 1.94-2.53 $\mathrm{kg} \mathrm{N}_{2} \mathrm{O}-\mathrm{N} \mathrm{ha}^{-1}$ range by (Neufeldt et al., 2006) for the Baden-Wurtemberg region of Germany.

There was a stark contrast between winter- and spring-sown crops, with emissions being higher by a factor of 2 for the latter compared to the former. This may be explained by the fact that $\mathrm{Nf}$ application occurred later in the season for spring crops, when temperature conditions are more conducive for nitrification and denitrification. These processes may also be enhanced because 
of the build-up of inorganic $\mathrm{N}$ from spring mineralization of soil organic matter under the bare soil preceding the planting of spring crops. However, this may be a specific to the environmental conditions of Picardie. In Baden-Wurtemberg, an opposite trend was noted with winter cereals emitting slightly more $\mathrm{N}_{2} \mathrm{O}$ than spring types (Neufeldt et al., 2006). This highlights the interplay between climate, soil conditions and crop management which may produce different outcomes depending on their respective dynamics.

Besides, the response pattern to the Nf input differed significantly between cases, to the extent that in a 2 cases out of 12 (involving soft wheat crops) the model simulated a decrease of $\mathrm{N}_{2} \mathrm{O}$ emissions when Nf increased. This may be seen for case 6 on Figure 3, and was actually due to the fractionation scheme for fertilizer application, which changed around that rate. Under a total dose of $80 \mathrm{~kg} \mathrm{~N} \mathrm{ha}^{-1}$, fertilizer was applied all at once in mid-April, whereas it was split into 2 applications (early March and mid-April) above. This split resulted in a higher growth potential for the wheat in early spring, and a higher $\mathrm{N}$ use efficiency (and hence lower emissions) following subsequent Nf inputs. This feedback leading to counter-intuitive results may still be an artefact of the model simulations, but nevertheless reflects the long-established agronomic principle that split applications increase Nf use efficiency. The resulting regression curve was somewhat sensitive to the 4 first data points, since shifting them down to force a monotonic response increased its slope from $0.58 \%$ to $0.70 \%$. This slight variation would have had limited consequences in the economic modeling, and we kept the original simulation curves to maintain the consistency of the models' coupling. Note that the economic model uses the regression coefficients (and not the jagged simulation line itself). Other than that, the response curves obtained with CERES-EGC for the different cases varied according to of one or several of their specific parameters: soil and crop types, sowing date, and previous crop.

The straight lines (noted Bouwman assessment) on Figure 3 represent the $\mathrm{N}_{2} \mathrm{O}$ emissions as- 
sessments according to the equation $E_{N_{2} \mathrm{O}}=1+0.0125 * N f$, with $E_{\mathrm{N}_{2} \mathrm{O}}$ is the annual direct

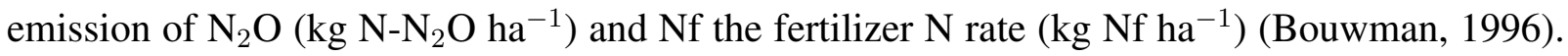
This linear model is used as the default IPCC methodology (Tier 1) (Houghton et al., 1996), and represents the current calculation of the $\mathrm{N}_{2} \mathrm{O}$ emissions in the AROPAj economic model, with the difference that the background emissions (in the absence $\mathrm{Nf}$ inputs) are not taken into account. The Bouwman equation and the CERES-EGC response curves never matched, whether regarding the background emission rates or the slope of the curves. Depending on the cases, the former led to either lower of higher estimates than those resulting from the biophysical modeling. Such discrepancies were also noted in a study on $\mathrm{N}_{2} \mathrm{O}$ emissions from winter wheat crops in a neighboring region, where the modeled $\mathrm{N}_{2} \mathrm{O}$ emissions were $40 \%$ to $80 \%$ lower than estimated with the Tier 1 emission factor (Gabrielle et al., 2006b). When compared with observations at the field-scale, the CERES-EGC model had a mean deviation typically ranging (in absolute values) from less than 1 to $5 \mathrm{~g} \mathrm{~N}-\mathrm{N}_{2} \mathrm{O}$ ha $^{-1} \mathrm{~d}^{-1}$ (Gabrielle et al., 2006a,b), which may be considered as resulting in unbiased predictions at the yearly scale given the high temporal variability of these fluxes (Hénault et al., 2005). These gaps between the two estimation methods also stress the importance of a finer assessment of the $\mathrm{N}_{2} \mathrm{O}$ emissions with a biophysical model that can take into account regional variations in soil and climate conditions, along with crop management practices.

While CERES-EGC model was only applied to one year, the inter-annual variability of climate was likely to affect its simulation of $\mathrm{N}_{2} \mathrm{O}$ emissions in the long run. In a study on GHG emissions from arable crops in the same region, Gabrielle and Gagnaire (2007) found coefficients of variations of up to $80 \%$ across the years when running the same model on a 30 -yr series of past weather data. However, the differences between crops were persistent over the years, as did the discrepancies between the IPCC Tier 1 estimates and the modeled emissions. Thus, inter-annual variability should not undermine the tendency obtained with the particular year we used here 
when comparing our biophysical/economic modeling with approaches that fully ignore soil and climate variability. From a quantitative point of view, and to put our particular simulation year into prospective, it should lastly be mentioned that it led to $\mathrm{N}_{2} \mathrm{O}$ emission levels $30 \%$ lower than the 30-yr average for the cases simulated here. Thus, the discrepancies with the IPCC Tier 1 estimates were probably slightly over-emphasized.

\subsubsection{Regression analysis and link with economic model}

The $\mathrm{N}_{2} \mathrm{O}$ response curves simulated by CERES-EGC for the various cases were input to the economic model AROPAj in the form of linear regression coefficients. Note that the rather variable levels of background emissions, in the absence of fertilizer inputs (ranging from 0.37 to $3.67 \mathrm{~kg}$ $\mathrm{N}_{2} \mathrm{O}-\mathrm{N} \mathrm{ha}{ }^{-1}$ ), were not input to AROPAj, since they were deemed natural and not anthropogenic. However, the fact that they varied across crops (contrary to the Bouwman (1996) equation) underlines the arbitraty limitation of this convention. Table 6 presents the characteristics of the linear regressions of $\mathrm{N}_{2} \mathrm{O}$ emissions against $\mathrm{Nf}$ inputs.

[Table 6 about here.]

The linear regressions fitted the $\mathrm{N}_{2} \mathrm{O}$ emission response curves rather well, with $\mathrm{R}$-squared values ranging above 0.80 in 8 cases out of 12. Such pattern was also reported by Neufeldt et al. (2006) with the biophysical model DNDC in the Baden-Wurtemberg region of Germany, with an $R^{2}$ of 0.79 for the same types of crops and $\mathrm{Nf}$ rates ranging from 40 to $250 \mathrm{~kg} \mathrm{~N} \mathrm{ha}^{-1}$. However, for two cases involving soft wheat, the $\mathrm{N}_{2} \mathrm{O}$ emissions curves presented an important dip (see case 6 on Figure 3). This particular pattern in the response curve was ignored by the linear regression, and resulted in poorer $\mathrm{R}^{2}$ values. Non-linear models were also tested, including an exponential model, which achieved a better fit and a lower residual standard error. However, the latter remained relatively low and acceptable with the linear models, being for instance of only $0.13 \mathrm{~kg} \mathrm{~N}_{2} \mathrm{O}-\mathrm{N} \mathrm{ha} \mathrm{h}^{-1}$ for the wheat crops, i.e. less than $10 \%$ of the annual total for the 
optimal fertilizer rate. We reverted to the liner model, considering it sufficient to address the first-order effect of our approach, which stems from the slope of the regression curve being in sharp contrast with the Tier 1 IPCC emission factor. Deviations from the linear response curves are a second-order effect, which would be worth tackling in future work.

\subsection{Impacts of response functions to nitrogen input in economic modeling.}

\subsubsection{Regional GHG emissions and economic margins}

[Figure 4 about here.]

[Figure 5 about here.]

Figures 4 and 5 present the AROPAj results for the $\mathrm{N}_{2} \mathrm{O}$ emissions and the global GHG emissions for the whole Picardie region. The emission factors obtained with CERES-EGC led to a reduced estimate of $\mathrm{N}_{2} \mathrm{O}$ emissions, whether with the exogenous or endogenous yields, with a $20 \%$ decrease compared to the IPCC estimate. Whatever the emission factors, the emissions of $\mathrm{N}_{2} \mathrm{O}$ were also $30 \%$ lower with the endogenous yields than with the exogenous ones. This could be expected, since the use of yield response curves allowed a higher efficiency of fertilizer use by crops, and thus led to an overall reduction in fertilizer consumption by farmers. With the endogenous yields, the model was also more reactive to the CAP 'Agenda 2000' scenario, resulting in changes in the management of each farm type: the areas allocated to each crop were slightly modified, as well as crop yields, so were the GHG emissions.

Total GHG emissions followed the same pattern as the $\mathrm{N}_{2} \mathrm{O}$ emissions across the simulation scenarios (Figure 5), being lower with the CERES-EGC emission factors compared to the IPCC one, and lowest with the endogenous yields. Obviously, GHG emissions from animals were not affected by the choice of the $\mathrm{N}_{2} \mathrm{O}$ emission factors. On the one hand, as was expected, the gross margins, crop areas and crop productivity levels calculated by AROPAj were not impacted by the changes in $\mathrm{N}_{2} \mathrm{O}$ emissions' estimates (IPCC vs CERES). On the other hand, changes in the 
yield assessment method in AROPAj (EXOG vs ENDOG) strongly affected the AROPAj results. The total gross margin increased by $5 \%$ with the endogenous method compared to the exogenous one, reflecting the higher efficiency of $\mathrm{Nf}$ inputs and marketable yield levels permitted by the yield response curves. This increase was higher for the arable crops specialized farm types (CrPi1 and $\mathrm{CrPi} 2$ ), and lower for the livestock-oriented farm types. The total arable area of the farm types was not modified because the AROPAj model considers them as constant. Nevertheless, the breakdown of arable area among crops was modified: there was a slight increase in cereal crops, industrial crops and pea, and a decrease in fodder crops.

\subsubsection{Mitigation measures and taxation schemes}

Various tax policies may be implemented within AROPAj, using different parameter sets. In order to mitigate the total GHG emissions, and thereby the emissions of $\mathrm{N}_{2} \mathrm{O}$, we enforced two taxation schemes: a first-best scheme directly taxing the GHG emissions; and a second-best scheme taxing the presumed factors behind the GHG emissions.

\section{Direct taxation of GHG emissions}

[Figure 6 about here.]

We studied for each of the simulation scenarios presented in Table 1 the effects of an increasing tax on the GHG emissions, ranging from 0 to $100 €$ per $\mathrm{t}-\mathrm{CO}_{2}$-eq. Figure 6 presents the results for the Picardie region regarding the total GHG emissions and their abatement. As expected, the GHG emissions decreased as the tax level increased, for all simulation scenarios. The major difference between the scenarios was due to the yield assessment method: GHG emissions were significantly higher with the exogenous method than with the endogenous one. This could be expected since farmers have more degrees of freedom avaiable with the endogenous yield determination to maximize $\mathrm{N}$ use efficiency and abate GHG emissions than with the fixed, exogenous 
yields. The rate of abatement was also higher with the endogenous yields. However, these patterns were affected by the $\mathrm{N}_{2} \mathrm{O}$ emission factors, which drastically changed the magnitude of the emissions, and to a minor extent the abatement rates. Examination of the level of tax needed to achieve a given target of GHG mitigation corroborates this analysis. The three horizontal lines on Figure 6 present three mitigation targets of 4, 8 and 12\% compared to the baseline emissions (ie in the absence of GHG-related taxes). Their intersection with the GHG emission curves obtained with the four simulation scenarios provide an estimate of the tax level required to meet these targets, which are quantified in Table 7.

[Table 7 about here.]

Higher taxes on GHG emissions were necessary to reach a given mitigation target with the exogenous yield assessment compared to the endogenous one. This gap widened as the mitigation target increased: taxes with the exogenous yields were twice higher than with the endogenous yields for the $4 \%$ mitigation target, and 3 to 4 times higher for the $8 \%$ target. Differences between the $\mathrm{N}_{2} \mathrm{O}$ assessment methods were also evidenced. Generally, the tax level needed to achieve a given mitigation target was slightly higher when using the CERES-EGC emission factors than the IPCC one, and this gap widened as the mitigation target increased. with the endogenous method than with the exogenous one. Indeed, the former allows a better 
reactivity of the farmer to changes in crop prices, and thereby to political measures. These gross margin results also evidence small differences due to the use of the CERES-EGC emission factor, which became more pronounced as the tax level increased.

This first-best tax on GHG emissions allows the public regulator to reach ambitious target of environmental damage abatement. However, such taxation is very costly to implement because each farmer's GHG emissions must be precisely known. Economically and practically speaking, it is unfeasible to measure these GHG emissions on each arable field. That is why we also compared that first-best scheme with its alternative, a second-best scheme taxing the presumed factors of the environmental damage.

\section{Taxing the presumed factors of the GHG emissions}

AROPAj calculates the emissions of two GHG: methane $\left(\mathrm{CH}_{4}\right)$ and $\mathrm{N}_{2} \mathrm{O}$. Because farming activities are globally affected by any change in the economic environment, changes in land allocation between marketed crops, fodder crops and pastures (linked to livestock farming) have to be implemented in our framework. We thus included the methane emissions and livestock activities in the below results. As livestock or nitrogen fertilizer consumption are easily observable factors (through the CAP or the markets), they may serve as a basis for a second-best GHG mitigation policy. It would lead to tax the livestock population and the fertilizer use of each farm type. We thus implemented such a scheme in the AROPAj model, and its effects on GHG emissions using the four simulation scenarios of Table 1 .

[Figure 8 about here.]

Figure 8 presents the results of AROPAj simulations with a combination of two taxes: one on Livestock Units ${ }^{2}$ (in $€ / \mathrm{LU}$ ) and one on nitrogen fertilizer input (in $€ / \mathrm{t} \mathrm{Nf}$ ). The curves present the combined tax needed to reach a certain level of reduction ( 2 to $12 \%$ reduction of the total 
GHG emissions - in relation to the baseline level of emissions). Similar to the first-best taxation, important differences occurred between the exogenous and endogenous yield assessment methods. With the exogenous yields, reasonable mitigation targets were harder to reach: a $2 \%$ or higher reduction in GHG emissions required both taxes on LU and $\mathrm{Nf}$ to be higher than $200 €$ (per LU or t Nf). With the endogenous yields, such tax levels make it possible to abate the emissions by more than $10 \%$. It is important to note that in the current implementation of AROPAj, contrary to crop yields, animal productions are not optimized against their production factors. The production levels of meat or milk are not related to the levels of animal feed supply. Obviously, such assessment would confer more reactivity to the model, and a more realistic response to the second-best taxation. The graphs also show an effect of the method used for the assessment of $\mathrm{N}_{2} \mathrm{O}$ emissions. Overall, the taxes were higher with the CERES-EGC emission factors than with the IPCC one for the same reduction target. Using the endogenous yields, a $12 \%$ reduction of the GHG emissions was attained with a tax on fertilizer $\mathrm{N}$ ranging from 180 to $250 € / \mathrm{t} \mathrm{N}$ with the IPCC emission factor, compared to a 240 to $250 € / \mathrm{t} \mathrm{N}$ range with the CERES-EGC emission factors.

Second-best taxes should be quite high to reach a given target of GHG emission abatement, much higher than the first-best tax when expressed in $€ / t-\mathrm{CO}_{2}$ eq abated through the physical relationship between the factor and the emission. For an $8 \%$ reduction in GHG emissions, the first-best tax was around $11 € / t-\mathrm{CO}_{2}$ eq, whereas the second-best tax could reach as high as $125 € / \mathrm{t} \mathrm{N}$ and $110 € / \mathrm{LU}$. Considering that $1 \mathrm{t}$ of $\mathrm{Nf}$ produces about $4 \mathrm{t}-\mathrm{CO}_{2}$ eq, and that $1 \mathrm{LU}$ produces $3 \mathrm{t}-\mathrm{CO}_{2}$ eq, the equivalent tax on $\mathrm{GHG}$ emissions for the second-best taxation would be $68 € / \mathrm{t}-\mathrm{CO}_{2}$ eq, i.e. 6 times higher than the first-best tax. Moreover, the relative efficiency of the second best tax scheme compared to first-best one may be highly dependent on the abatement target. Therefore, an analysis of costs and profits of the various taxation policies needs to be 
done in order to compare the efficiency of the 2 taxes more rigorously.

\section{Conclusion}

The IPCC Tier 1 methodology is currently widely used to assess greenhouse gas emissions - and in particular $\mathrm{N}_{2} \mathrm{O}$ emissions from agriculture. However, this methodology is relatively imprecise when used at the regional scale as it ignores the effect of the local environment. This paper explored an alternative methodology to assess the $\mathrm{N}_{2} \mathrm{O}$ emissions by coupling a biophysical soilcrop model to a micro-economic farm model. The biophysical model CERES-EGC enabled a fine assessment of $\mathrm{N}_{2} \mathrm{O}$ emissions, as related to local environmental conditions, and the economic model AROPAj enabled the generalization of the $\mathrm{N}_{2} \mathrm{O}$ results at the level of farm types representative of actual farms. The paper also studied possible policy measures to mitigate GHG emissions.

A series of cases representing different soil and crop management characteristics was set up in the Picardie region, based on an analysis of various comprehensive databases. Response curves of $\mathrm{N}_{2} \mathrm{O}$ emissions to $\mathrm{Nf}$ inputs were built for these cases, and fitted with a linear regression function. The slopes of these regressions ranged from $0.10 \%$ to $2.25 \%$ depending on the cases, whereas the IPCC default method considered a constant $1.25 \%$ emission factor. These slopes were input to the economic model AROPAj as new emission factors depending on crop type and farm type. Four simulation scenarios were run with AROPAj: crop yields were either exogenous or endogenous using yield response curves to nitrogen input, and the $\mathrm{N}_{2} \mathrm{O}$ emission factors were either obtained from the biophysical model or set at the IPCC value. The use of the modeled emission factors resulted in a $20 \%$ decrease in the magnitude of $\mathrm{N}_{2} \mathrm{O}$ emissions compared to the IPCC estimate. Thus, taking into account the yield response functions to Nf inputs appeared beneficial to the economic modeling. 
AROPAj allowed us to study two different greenhouse gas mitigation measures: a first-best tax on GHG emissions, and a second-best tax on the presumed factors of the GHG emissions (livestock and Nf inputs). Interestingly, the simulation variants (using exogenous or endogenous yields, and IPCC or CERES-EGC $\mathrm{N}_{2} \mathrm{O}$ emission factors) had a marked influence in the response to taxes, and thereby in the conclusions that could be drawn on the efficiency of the mitigation policies. With the first-best scheme, the discrepancies between the scenarios led to a tax range of 11 to $53 € / t-\mathrm{CO}_{2}$ eq for an $8 \%$ reduction of the $\mathrm{GHG}$ emissions. The gap was firstly due to the yield assessment method: the reduction of the GHG emissions was more pronounced with the endogenous yields as the tax increased. For high level of taxes (up to $50 € / \mathrm{t}-\mathrm{CO}_{2}$ eq), differences due to the $\mathrm{N}_{2} \mathrm{O}$ emission factors started to appear. A similar pattern was observed with the second-best taxation scheme. Endogenous yields conferred a higher reactivity to the model, and mitigation targets were easier to reach than with the exogenous yields. However, the taxes were higher than with the first-best taxation: an $8 \%$ abatement of GHG emissions required, for instance, a tax of $110 €$ per livestock unit and a tax of $125 €$ per ton of fertilizer N. However, a detailed analysis of the costs and profits of each taxation scheme should be undertaken to compare the 2 types of taxation, and measure their respective efficiency.

The method we proposed here needs to be extended to a wider set of EU regions and crop types to improve its operational status. It also has the potential to address environmental impacts, such as related to the emissions of $\mathrm{NH}_{3}$ and $\mathrm{NO}_{3}^{-}$, which could be easily introduced into the economic analysis. It could also be interesting to use the best-fit model (which is not necessarily linear) to describe the response of $\mathrm{N}$ losses to $\mathrm{Nf}$ inputs, and introduce these functions in AROPAj. Implementing response functions of animal production (meat and milk) to animal feed supply levels in AROPAj is also an important issue, allowing a more realistic response of farmers to GHG 
taxation schemes.

\section{Notes}

${ }^{1}$ The theoretical economic second-best world is quite large and complex. In the wide body of literature on the subject, we refer readers to Henry (1989) for a review.

${ }^{2}$ Livestock Unit (LU) is a unit used in order to compare livestock size of different species or category of animals. It is based on the feeding demand of the animals.

\section{Acknowledgements}

This work was carried out as part of the GENEDEC project (FP6-502184), funded under the 6th Framework Program of the European Commission.

\section{References}

AGRESTE (1997), Picardie: Mémento Régional, French Ministry of Agriculture, Paris

Asman W, Sutton M and Schjerring J (1998) Ammonia: Emission, Atmospheric transport and Deposition. New Phytol 139:27-48

Beaudoin N, Saad J, Van Laethem C et al (2005) Nitrate leaching in intensive agriculture in Northern France: Effect of Farming practices, Soils and Crop rotations. Agric Ecosys Environ $111: 292-310$

Bouwman A (1996) Direct Emission of nitrous oxide from agricultural soils. Nutrient Cycling Agroecosys 46:53-70

Brisson N, Mary B, Ripoche D et al (1998) STICS: a Generic Model for the simulation of crops and their Water and Nitrogen Balances. I - Theory and parameterization applied to Wheat and Corn. Agronomie 18:311-346 
Chakir R, Debove E, Jayet PA (2005) Decoupling of direct payments: an application of the AROPAj model (preliminary results) projecting regionally differentiated impacts on the EU15 farming sector. Proceedings of Expert workshop: Implementing the CAP reform in the new Member States, EU Commission, Sevilla, 15 pp

CITEPA (2008) Inventaire des Emissions de Polluants Atmosphériques en France - Séries Sectorielles et Analyses Etendues. Technical report Centre Interprofessionnel Technique dÉtudes de la Pollution Atmospherique, Paris http://www.citepa.org/publications/SECTEN-fevrier2008.pdf. Accessed 2 December 2008.

De Cara S, Houzé M, Jayet PA (2005) Methane and Nitrous Oxide Emissions from Agriculture in the EU: A Spatial Assessment of Sources and Abatement Costs. Environ Resource Economics $32: 551-583$

De Cara S, Jayet PA (2000a) Emissions of Greenhouse Gases from agriculture: the heterogeneity of abatement costs in France. Eur Rev Agric Economics 27:281-303

De Cara S, Jayet PA (2000b) Régulation de 1' effet de serre d' origine agricole: puits de carbone et instruments de second rang.Economie et Prévision 143-144:37-46

Dobbie KE, McTaggart IP, Smith KA (1999) Nitrous oxide emissions from intensive agricultural systems: Variations between crops and seasons, key driving variables, and mean emission factors. J Geophys Res 104:26 891-26 899

Firestone MK Davidson EA (1989) Microbiological basis of NO and N2O production and consumption in soil. In: Exchange of trace gases between terrestrial ecosystems and the atmosphere. John Wiley \& Sons, New York, pp 7-21

Food and Agriculture Organization - United Nations Educational Scientific and Cultural Organization (1974) Soil Map of the World. Volume I: Legend. UNESCO, Paris 
Gabrielle B, Kengni L (1996) Analysis and field-evaluation of the CERES models' soil components: Nitrogen transfer and transformation. Soil Sci Soc Am J 60:142-149

Gabrielle B, Roche R, Angas P et al (2002) A priori parameterisation of the CERES soil-crop model and tests against several European data sets. Agronomie 22:119-132

Gabrielle B, Laville P, Hénault C et al (2006a) Simulation of nitrous oxide emissions from wheatcropped soils using CERES. Nutr Cycling Agroecosys 74:133-146

Gabrielle B, Laville P, Duval O et al (2006b) Process-based modeling of nitrous oxide emissions from wheat-cropped soils at the sub-regional scale. Global Biogeochem Cycles 20:GB4018

Gabrielle B, Gagnaire N (2008) Life-cycle assessment of straw use in bio-ethanol production: a case-study based on deterministic modelling. Biomass Bioenergy 32:431-441

Godard C (2005) Modeling of the yield response of arable crops to nitrogen, and integration into a European-scale economic model of agricultural supply. Application to the assessment of climate change impacts. $\mathrm{PhD}$ thesis, INA P-G, Paris (in French) http://pastel.paristech.org/2852/ Accessed 2 December 2008.

Godard C, Roger-Estrade J, Jayet PA et al (2008) Use of available information at a European level to construct crop nitrogen response curves for the regions of the EU. Agric Systems 97:68-92

Granli T, Bockman OC (1995) Nitrous oxide emissions from soils in warm climates. Fert Res 42:159-163

Hénault C, Bizouard F, Laville P et al (2005) Predicting in situ soil $\mathrm{N}_{2} \mathrm{O}$ emission using NOE algorithm and soil database. Global Change Biol 11:115-127

Henry C (1989) Microeconomics for public policy: helping the invisible hand. Oxford University Press, $164 \mathrm{pp}$ 
Herrmann B, Jones S, Fuhrer J et al (2001) N budget and NH3 exchange of a grass/clover crop at two levels of N application, Plant Soil 235:243-252

Houghton J, Meira Filho L, Lim B et al (1996) Revised 1996 IPCC Guidelines for National Greenhouse Gas Inventories (3 volumes), IPCC/OECD/IGES, Bracknell, UK

IPCC (2006) Guidelines for National Greenhouse Gas Inventories. Prepared by the National Greenhouse Gas Inventories Programme, Eggleston

Jayet P, Labonne J (2005) Impact of a reform of the Common Agricultural Policy via uncoupling. Economie et Prévision 167:15

Jones JW, Hoogenboom G, Porter CH et al (2003) DSSAT Cropping System Model. Eur J Agron $18: 235-265$

Kaiser E, Kohrs K, Kücke M et al (1998) Nitrous Oxide release from arable soil: importance of N-Fertilization, Crops and temporal variation. Soil Biol Biochem 30:1553-1563

King D, Daroussin J, Tavernier R (1994) Development of a soil geographic database from the soil map of the European Communities. Catena 21:37-56

Lehuger S, Gabrielle B, van Oijen M et al (2008) Bayesian calibration of the nitrous oxide emission module of an agro-ecosystem model. Agric Ecosys Environ (in the press).

Leip A, Marchi G, Koeble R et al (2008) Linking an economic model for European agriculture with a mechanistic model to estimate nitrogen and carbon losses from arable soils in Europe. Biogeosciences 5:73-94

Li C, Frolking SE, Frolking TA (1992) A model of nitrous oxide evolution from soils driven by rainfall events: 1. Model structure and sensitivity. J Geophys Res 97:9759-9776 
Lorgeou J, Souverain F (2003) Agroclimatic atlas for maize, Arvalis, Meteo France, Paris (in French)

Neufeldt H, Schäfer M, Angenendt E et al (2006) Disaggregated greenhouse gas emission inventories from agriculture via a coupled economic-ecosystem model. Agric Ecosys Environ $112: 233-240$

Rolland M, Gabrielle B, Laville P et al (2008) Modeling of nitric oxide emissions from temperate agricultural ecosystems. Nutr Cycling Agroecosys 80:75-93

Ruser R, Flessa H, Schilling R et al (2001) Effect of crop-specific field management and N fertilization on N2O emissions from a fine-loamy soil. Nutr Cycling Agroecosys 59:177-191

Schnebelen N, Nicoullaud B, Bourennane H et al (2004) Using the STICS model to predict nitrate leaching following agricultural practices. Agronomie 24:423-435

Smith KA, Thomson PE, Clayton H et al (1998) Effects of Temperature, Water content and Nitrogen fertilization on emissions of nitrous oxide by soils. Atmos Environ 32:3301-3309

Smith WN, Grant B, Desjardins R et al (2004) Estimates of the interannual variations of N2O emissions from agricultural soils in Canada. Nutr Cycling Agroecosys 68:37-45

van der Groot E (1998) Spatial interpolation of daily meteorological data for the crop growth monitoring system (CGMS). In: Bindi M, Gozzini B (Eds) Seminar on data spatial distribution in meteorology and climatology Volterra, 28 september-3 October 1997, Office for official publications of the European Communities, Luxembourg, pp. 141-153

Vatn A, Bakken L, Botterweg P et al (1999) ECECMOD: An interdisciplimary modelling system for analysing nutrient and soil losses from Agriculture. Ecol Economics 30:189-205 
Willekens A, Van Orshoven J, Feyen J (1998) Estimation of the phenological calendar, Kccurve and temperature sums for cereals, sugar beet, potato, sunflower and rapeseed across Pan Europe, Turkey, and the Maghreb countries by means of transfer procedures. Joint Research Center of the European Communities - Space Applications Institute - MARS Project, Leuven, $60 \mathrm{pp}$

WMO, WDCGG (2006) WMO Greenhouse Gas Bulletin: The State of Greenhouse Gases in the Atmosphere Using Global Observations through 2005. Technical report, World Meteorological Organization, Environnement Division, Atmospheric Research and Environment Programme and World Data Center for Greenhouse Gases, Japan Meteorological Agency http://www.wmo.int/pages/prog/arep/gaw/ghg/documents/ghg_bulletin3_F.pdf. Accessed 2 December 2008. 


\section{List of Figures}

1 Schematic of the CERES-EGC model: inputs, compartments, modules and outputs. 34

2 Schematic of the AROPAj model. . . . . . . . . . . . . . . . 35

3 Response curves of $\mathrm{N}_{2} \mathrm{O}$ emissions to $\mathrm{Nf}$ input, as simulated by CERES-EGC. The resulting linear regression and IPCC Tier 1 estimation lines (noted Bouwman) are also depicted. . . . . . . . . . . . . . . . . . . 36

$4 \quad \mathrm{~N}_{2} \mathrm{O}$ emissions from synthetic fertilizers (in $1000 \mathrm{t}$ of $\mathrm{CO}_{2}$-eq.) for the Picardie region. . . . . . . . . . . . . . . . . . . 37

5 Global GHG $\left(\mathrm{N}_{2} \mathrm{O}\right.$ and $\left.\mathrm{CH}_{4}\right)$ emissions from agriculture for the Picardie region (in $1000 \mathrm{t}$ of $\mathrm{CO}_{2}$-eq.), as calculated by the AROPAj model for the various yield and $\mathrm{N}_{2} \mathrm{O}$ estimation methods. . . . . . . . . . . . . . . . 38

6 Effect of a direct taxation of GHG emissions on the relative reduction of GHG emissions from agriculture in the Picardie region. The horizontal lines refer to target abatement levels of 4,8 and $12 \%$, resp. . . . . . . . . . . . . . 39

7 Variations of the total gross margin of Picardie agriculture with increasing taxes on $\mathrm{GHG}$ emissions. . . . . . . . . . . . . . . . . . . . . . . 40

8 Tax levels required to achieve various mitigation targets with the coupled secondbest taxes on livestock units (LU) and on fertilizer $\mathrm{N}$ inputs, for the Picardie region, with the various crop yield and $\mathrm{N}_{2} \mathrm{O}$ estimation methods. EXOG means that crop yields are kept constant for any one farm type while ENDOG uses the yield response curves. These methods are combined with two variants for $\mathrm{N}_{2} \mathrm{O}$ emissions: the IPCC Tier 1 emission factor, or the CERES-EGC derived factors. . 41 


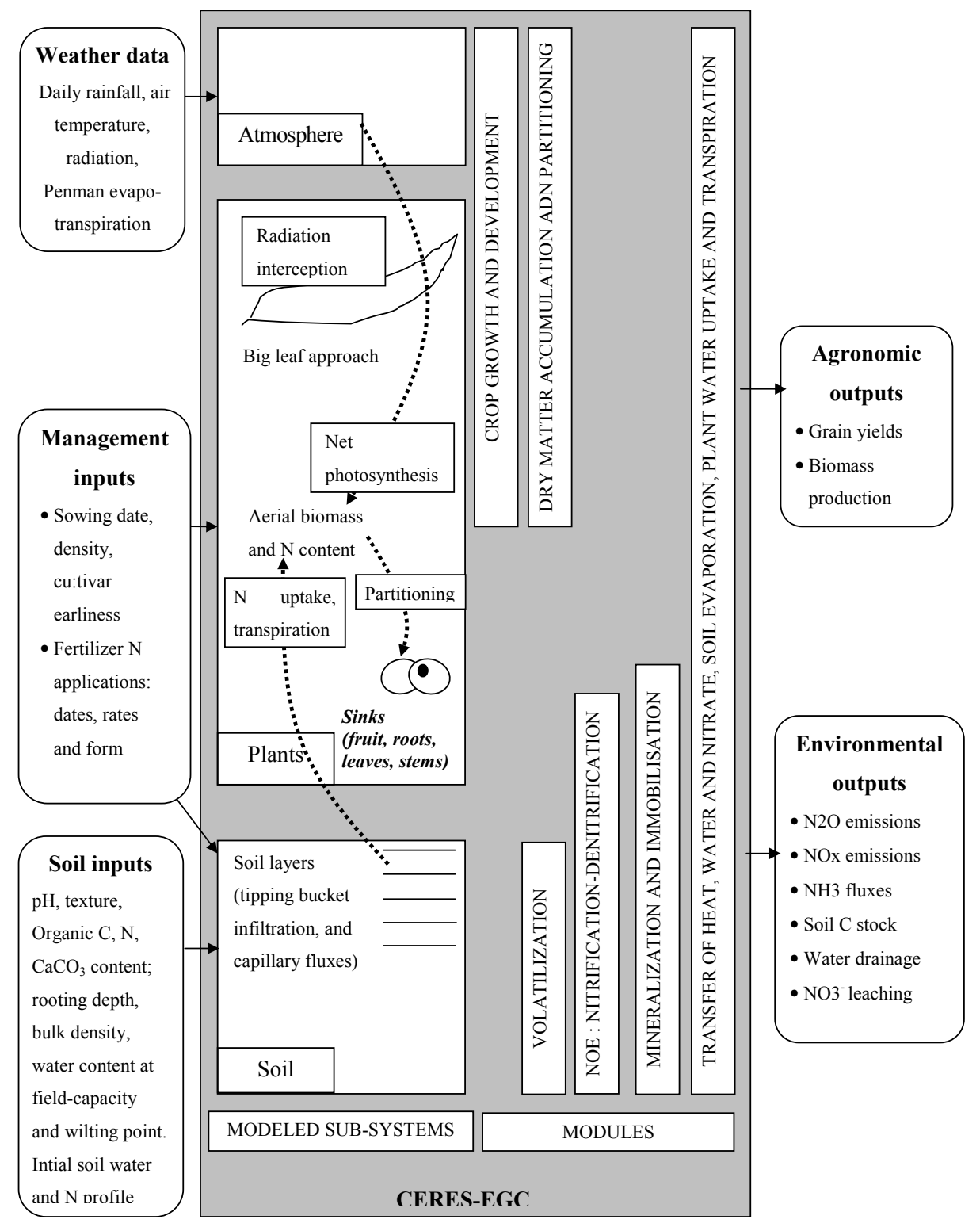

Figure 1: Schematic of the CERES-EGC model: inputs, compartments, modules and outputs. 


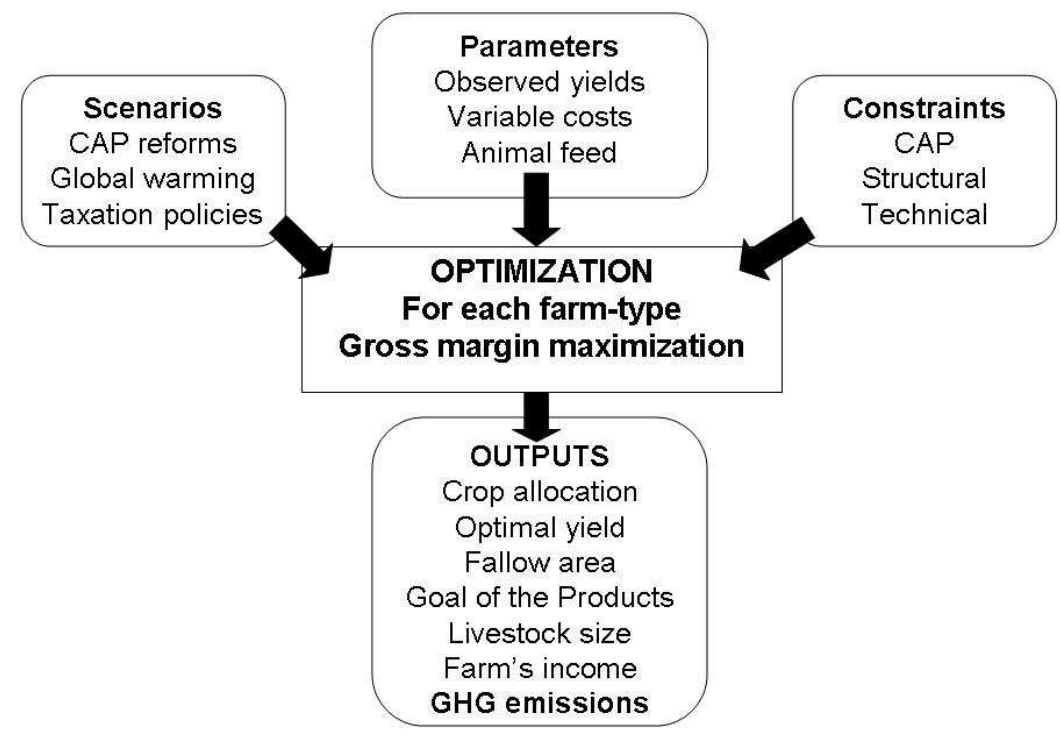

Figure 2: Schematic of the AROPAj model. 


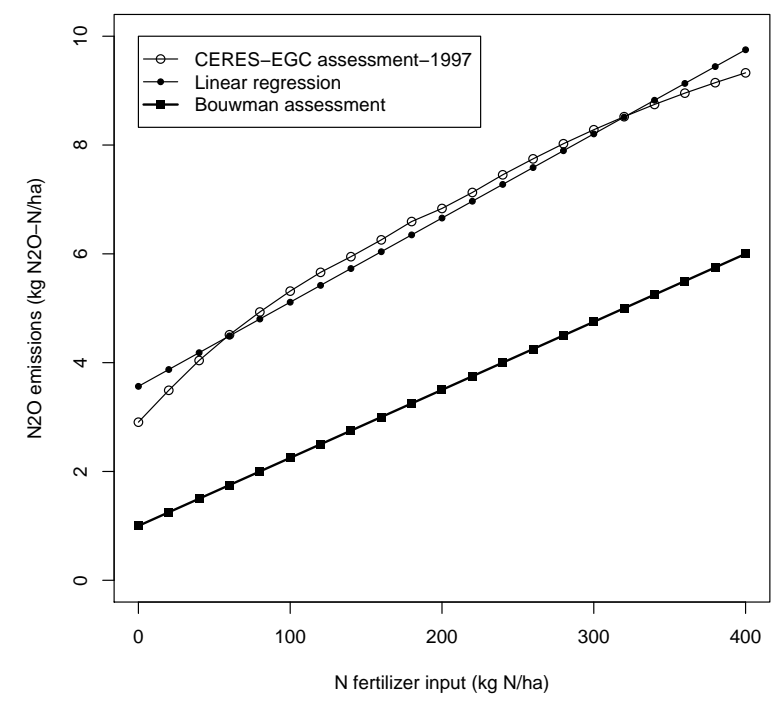

Case 2: Maize

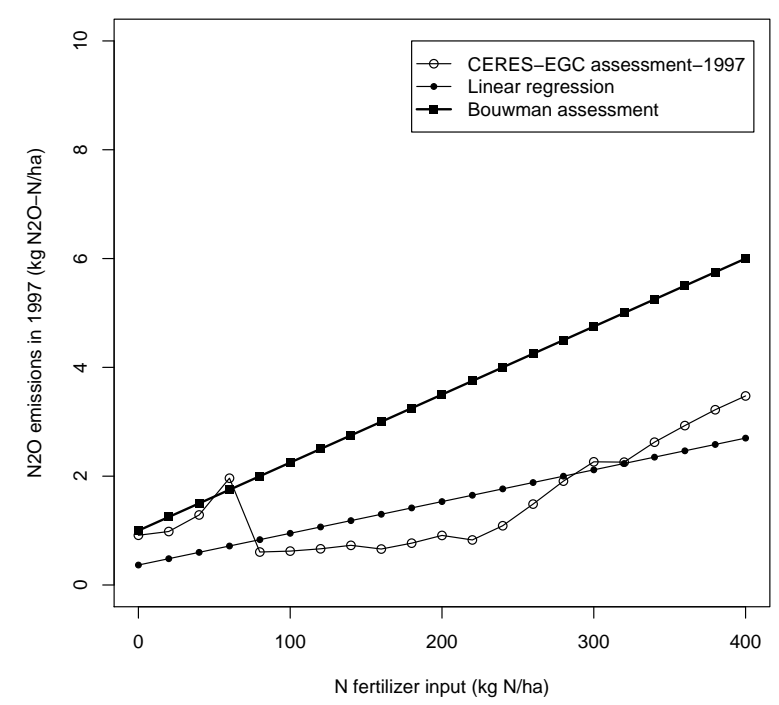

Case 6: Soft wheat

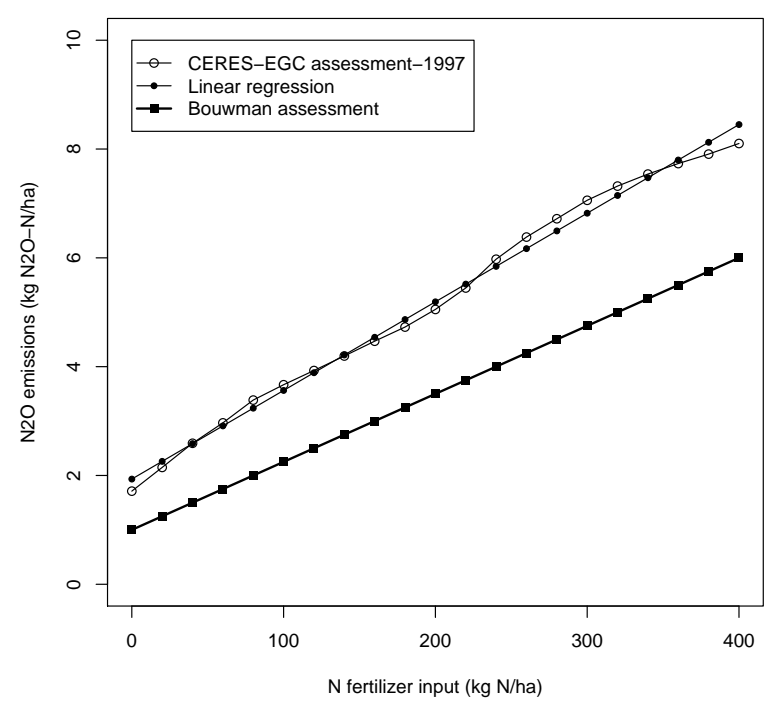

Case 5: Spring barley

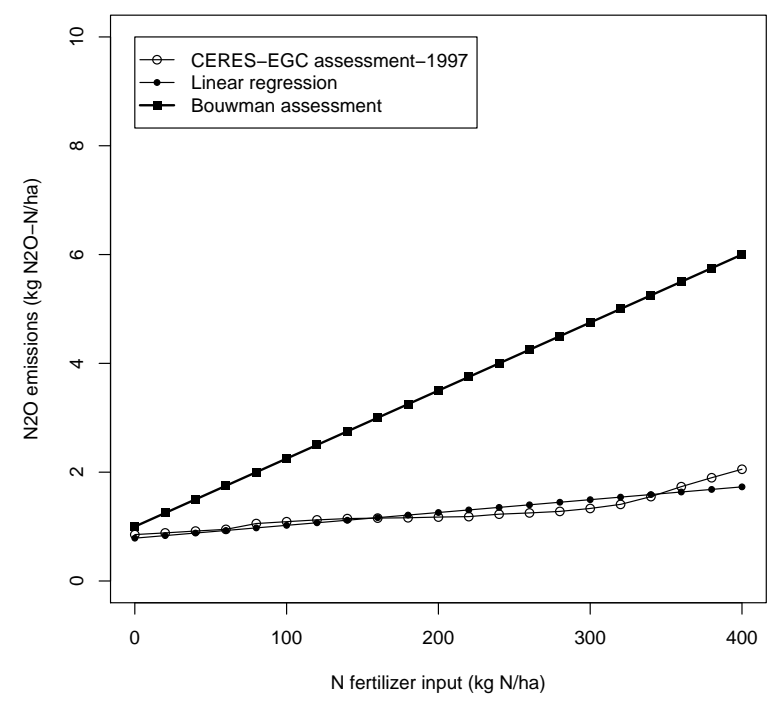

Case 12: Winter barley

Figure 3: Response curves of $\mathrm{N}_{2} \mathrm{O}$ emissions to $\mathrm{Nf}$ input, as simulated by CERES-EGC. The resulting linear regression and IPCC Tier 1 estimation lines (noted Bouwman) are also depicted. 


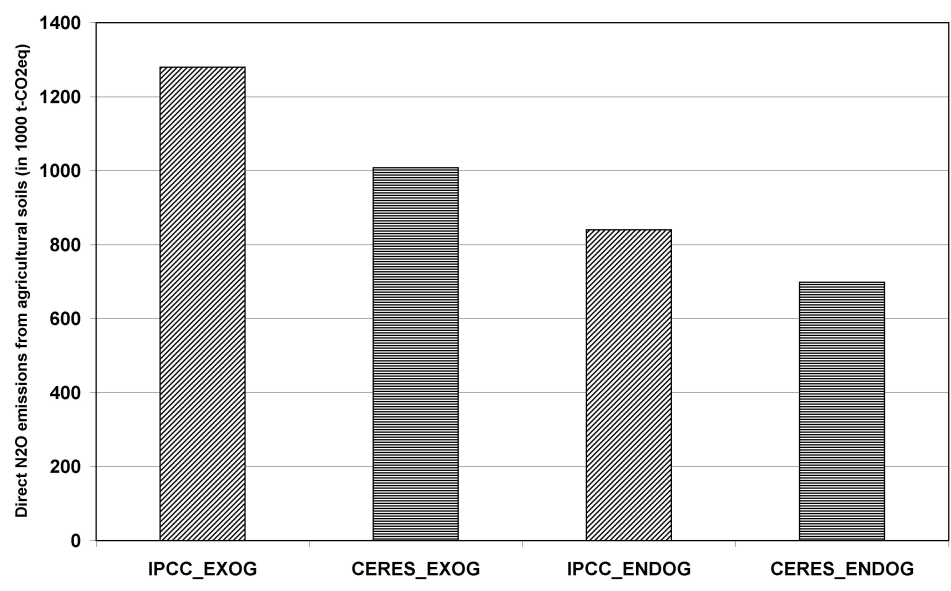

Figure 4: $\mathrm{N}_{2} \mathrm{O}$ emissions from synthetic fertilizers (in $1000 \mathrm{t}$ of $\mathrm{CO}_{2}$-eq.) for the Picardie region. 


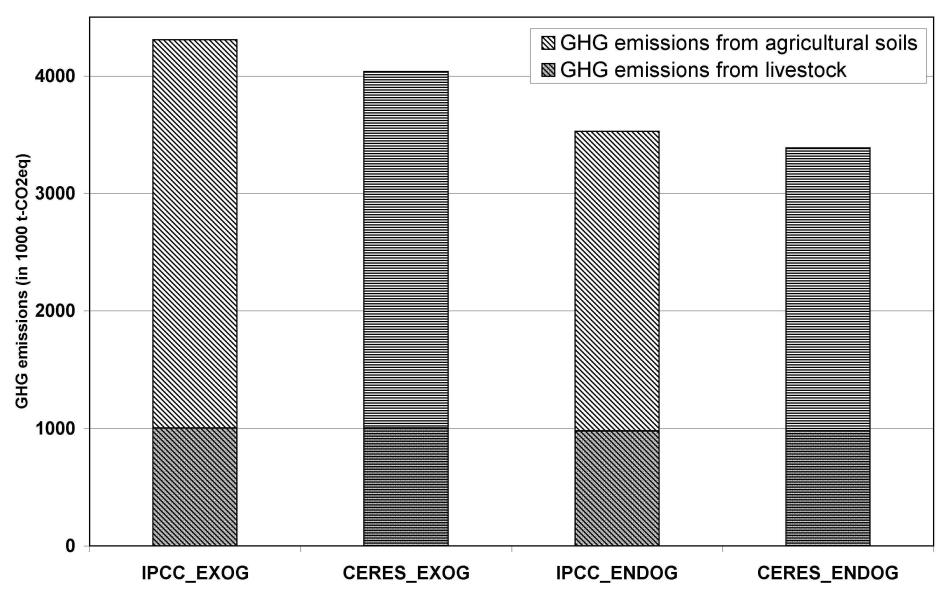

Figure 5: Global GHG $\left(\mathrm{N}_{2} \mathrm{O}\right.$ and $\left.\mathrm{CH}_{4}\right)$ emissions from agriculture for the Picardie region (in $1000 \mathrm{t}$ of $\mathrm{CO}_{2}$-eq.), as calculated by the AROPAj model for the various yield and $\mathrm{N}_{2} \mathrm{O}$ estimation methods. 


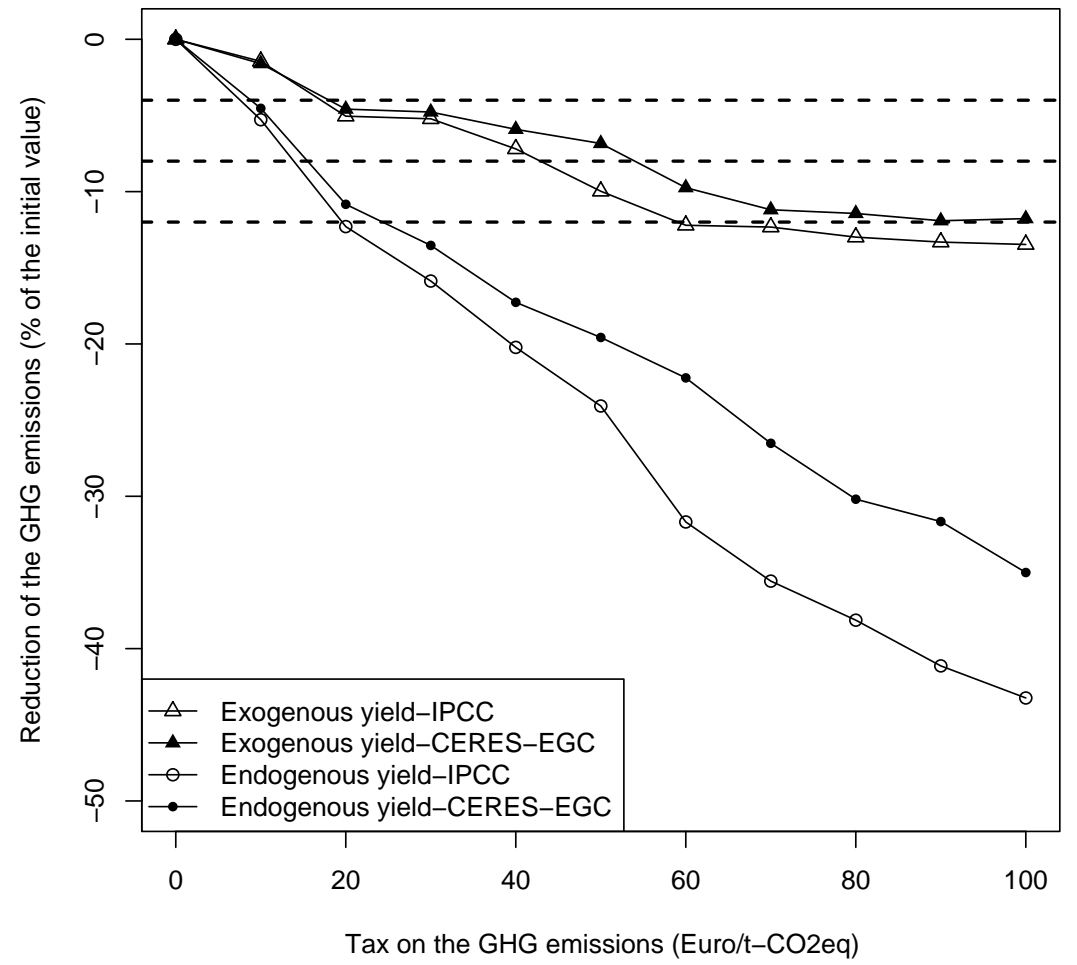

Figure 6: Effect of a direct taxation of GHG emissions on the relative reduction of GHG emissions from agriculture in the Picardie region. The horizontal lines refer to target abatement levels of 4,8 and $12 \%$, resp. 


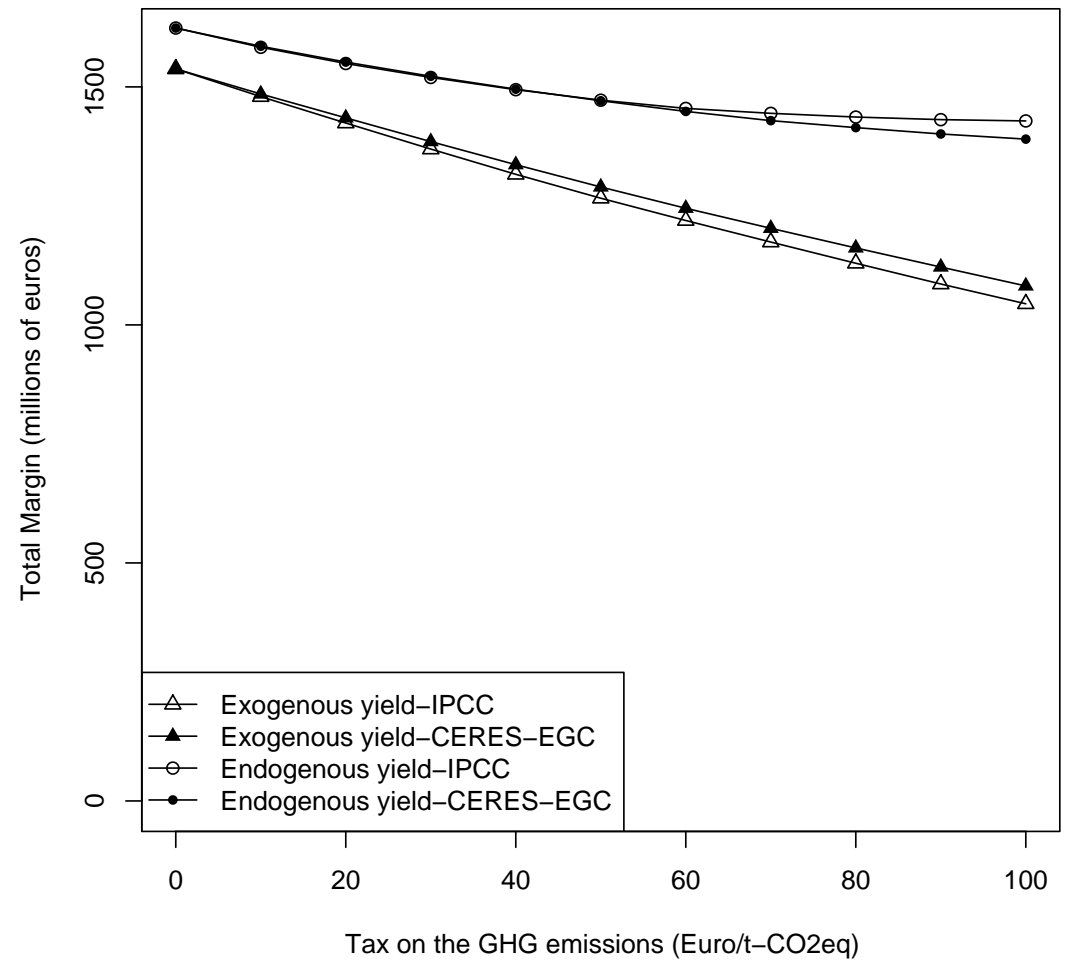

Figure 7: Variations of the total gross margin of Picardie agriculture with increasing taxes on GHG emissions. 

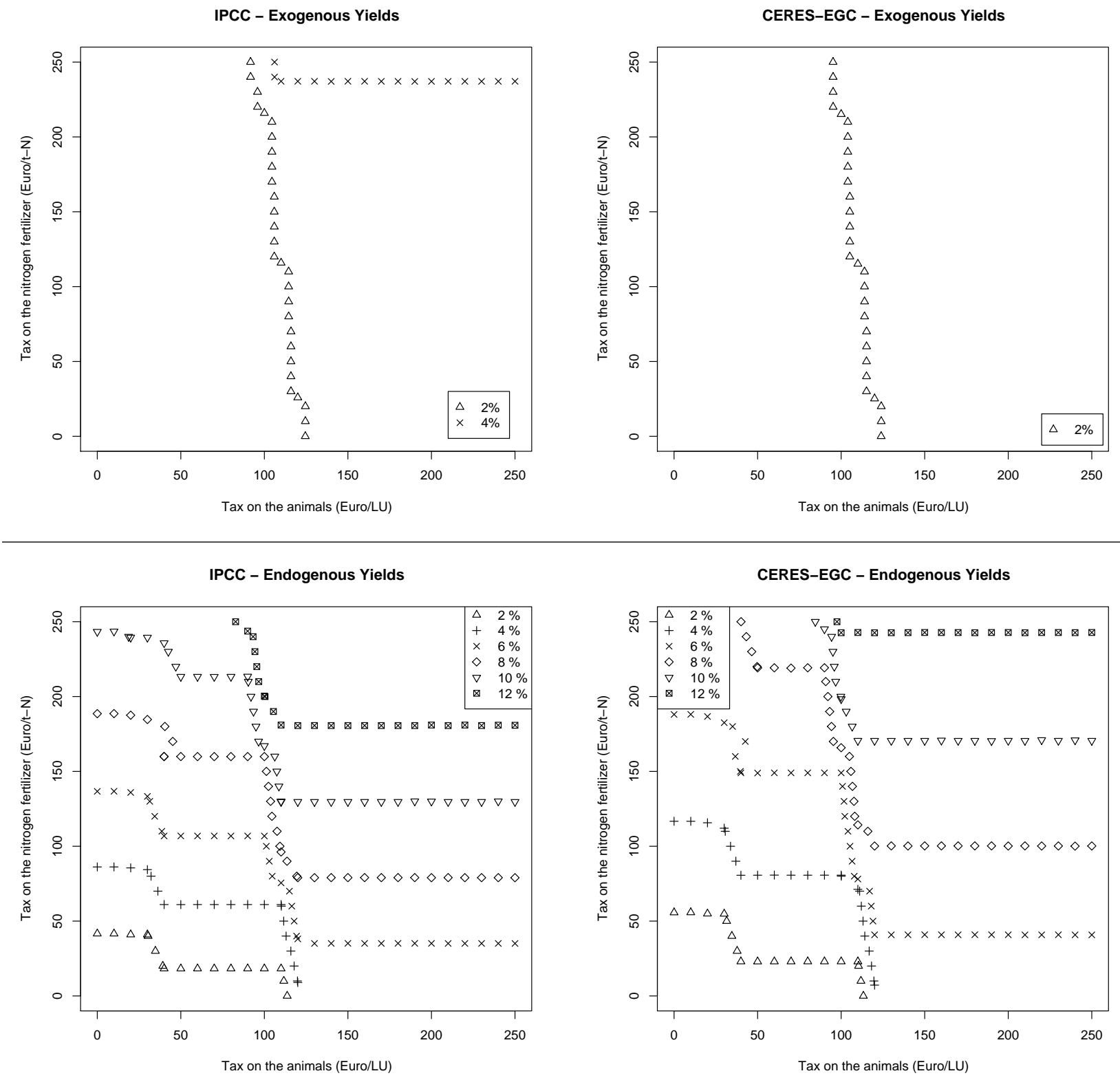

Figure 8: Tax levels required to achieve various mitigation targets with the coupled second-best taxes on livestock units (LU) and on fertilizer $\mathrm{N}$ inputs, for the Picardie region, with the various crop yield and $\mathrm{N}_{2} \mathrm{O}$ estimation methods. EXOG means that crop yields are kept constant for any one farm type while ENDOG uses the yield response curves. These methods are combined with two variants for $\mathrm{N}_{2} \mathrm{O}$ emissions: the IPCC Tier 1 emission factor, or the CERES-EGC derived factors. 


\section{List of Tables}

1 Characteristics of the AROPAj simulations regarding the yields and $\mathrm{N}_{2} \mathrm{O}$ emissions estimation methods. . . . . . . . . . . . . . . . . 43

2 Summary of the sources and methods for the determination of the STICS input data used for CERES-EGC (adapted from Godard et al. 2008). . . . . . . . . . . 44

3 Characteristics of the various simulation cases in Picardie. Farm types CrPi1 and $\mathrm{SCrPi} 2$ specialize in arable crops, whereas farm types $\mathrm{CaPi} 1$ and $\mathrm{CaPi} 2$ are mixed livestock-arable farms. Soil characteristics are given in Table 4 . . . . . . 45

4 Codes and selected characteristics of the soils used in the Picardie simulations. . 46

5 Crop types simulated with CERES-EGC and cultivated area in Picardie (AGRESTE, 1997). The area covered by these 6 crops made up $74 \%$ of the regional utilized arable area. . . . . . . . . . . . . . . . . . . 47

6 Coefficients of the linear regressions of $\mathrm{N}_{2} \mathrm{O}$ emissions against fertilizer $\mathrm{N}$ rates (Nf). The regression equation reads: $E_{N 2 O}=a \times N f+b$, where $E_{N 2 O}$ are the $\mathrm{N}_{2} \mathrm{O}$ emissions in $\mathrm{kg} \mathrm{N}_{2} \mathrm{ON} \mathrm{ha}{ }^{-1} \ldots \ldots \ldots \ldots . \ldots . \ldots . \ldots 48$

7 Tax levels (in euros/t-CO2-eq) required to achieve a set of GHG mitigation targets, as calculated with AROPAj with various methods to estimate yield and $\mathrm{N}_{2} \mathrm{O}$ emissions. . . . . . . . . . . . . . . . . . . . . 49 


\begin{tabular}{|c|c|c|}
\hline & Yield & $\mathrm{N}_{2} \mathrm{O}$ emissions \\
\hline IPCC-EXOG & Exogenous & $1.25 \%$ of Nf inputs \\
\hline CERES-EXOG & Exogenous & $\begin{array}{l}\text { Fraction of Nf inputs depending } \\
\text { on crop and farm types }\end{array}$ \\
\hline IPCC-ENDOG & Endogenous & $1.25 \%$ of Nf inputs \\
\hline CERES-ENDOG & Endogenous & $\begin{array}{l}\text { Fraction of Nf inputs depending } \\
\text { on crop and farm types }\end{array}$ \\
\hline
\end{tabular}

Table 1: Characteristics of the AROPAj simulations regarding the yields and $\mathrm{N}_{2} \mathrm{O}$ emissions estimation methods. 


\begin{tabular}{|c|c|c|}
\hline Inputs & Main information sources & Determination method \\
\hline Climate & $\begin{array}{l}\text { MARS }{ }^{1} \text { Project database (van } \\
\text { der Groot, 1998) }\end{array}$ & Climatic conditions based on altitude class \\
\hline Soil & $\begin{array}{l}\text { - 1:1,000,000 European geo- } \\
\text { graphical soil database (King } \\
\text { et al., 1994) } \\
\text { - Corine Land Cover } 2000^{2}\end{array}$ & $\begin{array}{l}\text { Aggregation of soil types with identical STICS } \\
\text { parameters and largest areas within the Picardie } \\
\text { region }\end{array}$ \\
\hline $\begin{array}{l}\text { Earliness }{ }^{3} \\
\text { group }\end{array}$ & $\begin{array}{l}\text { Lorgeou and Souverain } \\
(2008)\end{array}$ & \multirow{2}{*}{$\begin{array}{l}\text { Selection of one cultivar and one earliness } \\
\text { group depending on the crop, } \\
\text { and on the weight of the earliness factor in the } \\
\text { cultivar choice (Godard et al., 2008) }\end{array}$} \\
\hline $\begin{array}{l}\text { Sowing } \\
\text { date }\end{array}$ & $\begin{array}{l}\text { - Phenological MARS Project } \\
\text { database (Willekens et al., } \\
\text { 1998) } \\
\text { - Expert knowledge }\end{array}$ & \\
\hline $\begin{array}{l}\text { Preceding } \\
\text { crop }\end{array}$ & & $\begin{array}{l}\text { Wheat (non } \mathrm{N} \text {-fixing crop) or pea (N-fixing } \\
\text { crop) }\end{array}$ \\
\hline $\begin{array}{l}\text { Synthetic } \\
\text { fertilizer } \\
\mathrm{N} \text { inputs }\end{array}$ & $\begin{array}{l}\text { Expert knowledge and deci- } \\
\text { sion rules }\end{array}$ & $\begin{array}{l}\text { Fertilizer type(s) fully determined, splitting } \\
\text { of Nf applications according to development } \\
\text { stages (based on degree-days). }\end{array}$ \\
\hline $\begin{array}{l}\text { Organic } \\
\mathrm{N} \text { inputs }\end{array}$ & $\begin{array}{l}\text { - Expert knowledge and rules } \\
\text { - FADN }\end{array}$ & $\begin{array}{l}\text { Rates and types of manure spread } \\
\text { estimated from priority order and livestock esti- } \\
\text { mations by AROPAj from FADN }\end{array}$ \\
\hline
\end{tabular}

Table 2: Summary of the sources and methods for the determination of the STICS input data used for CERES-EGC (adapted from Godard et al. 2008).

1: MARS: Monitoring Agriculture from Remote Sensing.

2: http://www.ifen.fr/bases-de-donnees/occupation-du-sol.html

3: Earliness is a characteristic of a crop cultivar defining its maturity date.

4: FADN: Farm Accountancy Data Network. 


\begin{tabular}{ccccccc}
\hline Case & Crop & Farm type & Soil & $\begin{array}{c}\text { Earliness } \\
\text { Group }^{1}\end{array}$ & $\begin{array}{c}\text { Sowing } \\
\text { date }\end{array}$ & $\begin{array}{c}\text { Preceding } \\
\text { Crop }^{2}\end{array}$ \\
\hline $\begin{array}{c}\text { Spring crops } \\
\mathbf{1}\end{array}$ & Maize & CrPi1, CaPi1 & 1969 & 2 & 5 May 1997 & Wheat \\
$\mathbf{2}$ & Maize & CrPi2 & 1974 & 1 & 5 May 1997 & Pea \\
$\mathbf{3}$ & Sugar beet & CrPi 1-2, CaPi 1-2 & 1974 & RA $^{3}$ & 2 Apr. 1997 & Wheat \\
$\mathbf{4}$ & Spring Barley & CrPi1 & 1042 & RA & 16 Mar. 1997 & Wheat \\
$\mathbf{5}$ & Spring Barley & CaPi2 & 1974 & RA & 2 Feb. 1997 & Pea \\
\hline Winter crops & & & & & & \\
$\mathbf{6}$ & Soft wheat & CrPi1, CaPi 1-2 & 1042 & 1 & 15 Oct. 1996 & Pea \\
$\mathbf{7}$ & Soft wheat & CrPi2 & 1974 & 2 & 15 Oct. 1996 & Pea \\
$\mathbf{8}$ & Rapeseed & CrPi1 & 1042 & RA & 30 Aug. 1996 & Pea \\
$\mathbf{9}$ & Rapeseed & CrPi2, CaPi1 & 1974 & RA & 30 Aug. 1996 & Pea \\
$\mathbf{1 0}$ & Rapeseed & CaPi2 & 1974 & RA & 27 Aug. 1996 & Wheat \\
$\mathbf{1 1}$ & Winter Barley & CrPi2 & 1792 & RA & 31 Oct. 1996 & Wheat \\
$\mathbf{1 2}$ & Winter Barley & CaPi1 & 1974 & RA & 31 Oct. 1996 & Pea \\
\hline
\end{tabular}

1: Earliness is a characteristic of a crop cultivar defining its maturity date. It determines the dates of the various management intervention during the crop growing cycle. Cultivars belonging to 'earliness group 1' have an earlier maturity than those of 'earliness group 2'.

2: The preceding crop 'Pea' is not fertilized whereas 'Wheat' is fertilized with $200 \mathrm{~kg} \mathrm{~N} \mathrm{ha}^{-1}$.

3: RA: regional average.

Table 3: Characteristics of the various simulation cases in Picardie. Farm types CrPi1 and SCrPi2 specialize in arable crops, whereas farm types $\mathrm{CaPi} 1$ and $\mathrm{CaPi} 2$ are mixed livestock-arable farms. Soil characteristics are given in Table 4. 


\begin{tabular}{llccccc}
\hline $\begin{array}{c}\text { Soil } \\
\text { code }\end{array}$ & \multicolumn{1}{c}{$\begin{array}{c}\text { FAO } \\
\text { Classification }\end{array}$} & $\begin{array}{c}\mathrm{PAW} \\
\mathrm{mm}\end{array}$ & $\begin{array}{c}\mathrm{pH} \\
\text { value }\end{array}$ & $\begin{array}{c}\text { Organic } \\
\text { carbon } \\
\mathrm{g} \mathrm{kg}^{-1}\end{array}$ & $\begin{array}{c}\mathrm{CaCO}_{3} \\
\text { content } \\
\mathrm{g} \mathrm{kg}^{-1}\end{array}$ & $\mathrm{PDR}^{3}$ \\
\hline 1042 & Eutric Fluvisol & 150.6 & 6.5 & 10 & 10 & 8.0 \\
1792 & Calcic Cambisol & 118.4 & 8.0 & 18 & 50 & 3.4 \\
1969 & Orthic Luvisol & 189.6 & 6.5 & 10 & 0 & 16.0 \\
1974 & Calcaric Eutric Cambisol & 114 & 7.0 & 10 & 20 & 6.0 \\
\hline
\end{tabular}

1: FAO-UNESCO (1974)

${ }^{2}$ PAW: Plant Available Water.

${ }^{3}$ PDR: Potential Denitrification Rate (Hénault et al., 2005).

Table 4: Codes and selected characteristics of the soils used in the Picardie simulations. 


\begin{tabular}{lr}
\hline \multicolumn{1}{c}{ Crop type } & Area (ha) \\
\hline Soft wheat & 502343 \\
Maize & 35100 \\
Sugar beet & 166855 \\
Rapeseed & 37839 \\
Spring barley & 39286 \\
Winter barley & 91183 \\
\hline Total & 872606 \\
\hline
\end{tabular}

Table 5: Crop types simulated with CERES-EGC and cultivated area in Picardie (AGRESTE, 1997). The area covered by these 6 crops made up $74 \%$ of the regional utilized arable area. 


\begin{tabular}{cccccc}
\hline Case & Crop & $\mathrm{a}$ & $\mathrm{b}$ & $\begin{array}{c}\text { Residual } \\
\text { standard error }\end{array}$ & $\begin{array}{c}\text { Adjusted } \\
\text { R-squared }\end{array}$ \\
& type & $\%$ & \multicolumn{2}{c}{$\mathrm{kg} \mathrm{N}_{2} \mathrm{ON} \mathrm{ha}^{-1}$} & \\
\hline 1 & Maize & 0.83 & 1.01 & 0.36 & 0.89 \\
2 & Maize & 1.55 & 3.56 & 0.26 & 0.98 \\
3 & Sugar beet & 1.98 & 3.67 & 0.42 & 0.97 \\
4 & Spring Barley & 2.25 & 1.73 & 0.61 & 0.95 \\
5 & Spring Barley & 1.63 & 1.93 & 0.17 & 0.99 \\
6 & Wheat & 0.58 & 0.37 & 0.60 & 0.58 \\
7 & Wheat & 0.46 & 0.42 & 0.25 & 0.84 \\
8 & Rapeseed & 0.21 & 2.74 & 0.71 & 0.08 \\
9 & Rapeseed & 0.29 & 0.93 & 0.48 & 0.35 \\
10 & Rapeseed & 0.31 & 1.09 & 0.51 & 0.34 \\
11 & Winter Barley & 0.10 & 0.39 & 0.03 & 0.95 \\
12 & Winter Barley & 0.24 & 0.79 & 0.13 & 0.83 \\
\hline
\end{tabular}

Table 6: Coefficients of the linear regressions of $\mathrm{N}_{2} \mathrm{O}$ emissions against fertilizer $\mathrm{N}$ rates (Nf). The regression equation reads: $E_{N 2 O}=a \times N f+b$, where $E_{N 2 O}$ are the $\mathrm{N}_{2} \mathrm{O}$ emissions in $\mathrm{kg}$ $\mathrm{N}_{2} \mathrm{ON} \mathrm{ha}{ }^{-1}$. 


\begin{tabular}{ccccc}
\hline \multirow{2}{*}{ GHG emissions reduction } & \multicolumn{2}{c}{ Exogenous Yields } & \multicolumn{2}{c}{ Endogenous Yields } \\
\cline { 2 - 5 } & IPCC & CERES-EGC & IPCC & CERES-EGC \\
\hline $4 \%$ & 14.5 & 14 & 6.9 & 8 \\
$8 \%$ & 46 & 53 & 10.8 & 11 \\
$12 \%$ & 59 & 85 & 19 & 24 \\
\hline
\end{tabular}

Table 7: Tax levels (in euros/t-CO2-eq) required to achieve a set of GHG mitigation targets, as calculated with AROPAj with various methods to estimate yield and $\mathrm{N}_{2} \mathrm{O}$ emissions. 